PRZEGLĄD NAUK HISTORYCZNYCH 2017, R. XVI, NR 1

http://dx.doi.org/10.18778/1644-857X.16.01.06

REMIGIUSZ KASPRZYCKI

Uniwersytet Pedagogiczny w Krakowie”

\title{
Ucieczki do Polski żołnierzy z krajów sąsiednich w latach 1920-1939
}

Streszczenie. W latach 1920-1939 do Polski przedostało się co najmniej kilkuset dezerterów $z$ krajów sąsiednich. Schronienia szukali tu również żołnierze $z$ armii węgierskiej, a nawet francuskiej. Dezerterzy uciekali do Polski prześladowani na tle narodowościowym, religijnym i politycznym. Szczególnie dotyczyło to służących w Armii Czerwonej i Wehrmachcie. Wśród uciekinierów nie brakowało żołnierzy, którzy na terenie swoich krajów dopuścili się przestępstw. Charakteryzowało to zwłaszcza żołnierzy $z$ armii czechosłowackiej i rumuńskiej.

Dezerterzy $z$ państw obcych dopiero po wnikliwym przesłuchaniu i żmudnej weryfikacji mogli zostać zaliczeni do politycznych uchodźców, dla których poszukiwano miejsca zamieszkania i pracy. Postępowania wobec dezerterów z państw obcych zostały określone w rozporządzeniach w marcu i kwietniu $1923 \mathrm{r}$.

Takie postępowanie było konieczne ze względu na bezpieczeństwo państwa. W innym przypadku pozorny dezerter szybko okazywał się szpiegiem lub dywersantem. Mimo ograniczonego zaufania do dezerterów informacje uzyskane od zbiegów były niekiedy cennym materiałem wywiadowczym. Było tak m.in. wiosna 1936 r., kiedy przesłuchanie litewskiego dezertera znacznie rozszerzyło wiedzę polskiego wywiadu o tamtejszej armii.

Dezerterzy służyli również polskiej propagandzie, która szczególnie latem 1939 r. nagłaśniała przypadki ucieczek niemieckich żołnierzy do Polski. Działania takie miały na celu osłabienie morale armii niemieckiej a jednocześnie pokrzepienie własnych żołnierzy i obywateli.

Słowa kluczowe: dezercje, ucieczka, Polska, żołnierze, armia, kraje sąsiednie.

$\mathrm{P}$ roblem dezercji w Wojsku Polskim (dalej: WP) w latach 19181939 poruszało dotychczas wielu autorów. W ostatnich latach różna skalę tego zjawiska opisali m.in. Jerzy Grzybowski ${ }^{1}$,

* Instytut Bezpieczeństwa i Edukacji Obywatelskiej, e-mail: rmk402@interia.pl.

${ }^{1}$ J. Grzybowski, Białorusini $w$ polskich formacjach wojskowych $w$ latach 1918-1945, Warszawa 2006. 
Konrad Czernielewski i Witold Jarno ${ }^{2}$, a także Edward Jaroszuk ${ }^{3}$. Nigdy jednak nie skierowano wysiłków badawczych na zbiegostwo do przedwojennej Polski żołnierzy z krajów sąsiednich. Celem artykułu jest więc pionierska próba przedstawienia dezercji do naszego kraju żołnierzy z Niemiec, Związku Sowieckiego, Litwy, Czechosłowacji i Rumunii. W artykule starałem się dociec nie tylko skali dezercji czy motywów ucieczek dezerterów, lecz także polityki władz wojskowych i administracji państwowej wobec zbiegłych żołnierzy $z$ krajów sąsiednich. Powstały tekst w przeważającej mierze bazuje na dokumentach zgromadzonych w zespołach archiwalnych Archiwum Akt Nowych (dalej: AAN), Wojskowym Biurze Historycznym (dalej: WBH, tj. byłym Centralnym Archiwum Wojskowym), Archiwum Straży Granicznej (dalej: ASG), a także różnych oddziałach archiwów państwowych w Polsce. Jego uzupełnienie stanowia artykuły przedwojennej prasy, a także wybrana literatura.

Wojna Polski z Rosją bolszewicka wywołała nie tylko liczna dezercję polskich, lecz także bolszewickich żołnierzy. Tylko w sierpniu i wrześniu 1920 r. uciekło ponad 1100 bolszewickich żołnierzy. Byli to dezerterzy z 1 Armii Konnej (dalej: AK), 45 Dywizji Strzelców (dalej: DS), 11 Dywizji Konnej (dalej: DK), Floty Powietrznej 1 AK $\mathrm{i}$ innych. We wspomnianym czasie azyl w Polsce wybrało również 90 oficerów należących do komostawu, czyli dowództwa powyższych formacji oraz m.in. Zarządu Formacji Sanitarnych czy też Zarządu Zaopatrzenia. Według Aleksandra Smolińskiego wspomniana liczba bolszewickich dezerterów ma charakter orientacyjny ${ }^{4}$. Faktyczna liczba dezercji prawdopodobnie była znacznie większa.

Dezercja czerwonoarmistów była zjawiskiem występującym w dużej skali jeszcze w czasie ofensywnych sukcesów wojennych. Od końca maja do końca lipca 1920 r. z 1 AK Budionnego zdezerterowało blisko 1000 żołnierzy ${ }^{5}$. Po załamaniu się ofensywy w połowie sierpnia 1920 r. zbiegostwo $z$ oddziałów bolszewickich było już masowe. Poza jeńcami, których wzięto do niewoli w trakcie walk, liczba zbiegłych żołnierzy $z$ armii bolszewickiej wynosiła kilka tysięcy. Tego zjawiska nie powstrzymały nawet działania funkcjonującej od grudnia 1918 r. tzw. CTK ds. WD, czyli Centralnej Tymczasowej

${ }^{2}$ K. Czernielewski, W. Jarno, Garnizon Eódzki Wojska Polskiego 19181939, Toruń 2008.

${ }^{3}$ E. Jaroszuk, Żandarmeria Wojskowa w latach 1921-1939, Kraków 2009.

4 A. S molińs ki, Dezercje z 1 Armii Konnej podczas jej walk na polskim teatrze działań wojennych w 1920 r., Białystok 2008, s. 171-173.

${ }^{5}$ Ibidem, s. 168-169. 
Komisji ds. Walki z Dezercją. Dyrektywy płynące z Moskwy nakazywały surowe karanie dezerterów jako zdrajców proletariatu. Paradoksalnie jednak w rzeczywistości frontu polsko-bolszewickiego wojenne trybunały wielokrotnie okazywały łaskawość. Złapanych dezerterów często wcielano jedynie do innego pułku. Przykładowo: w sierpniu 1920 r. 58 dezerterów z 14 DK 1 AK przeniesiono do 2 pułku zapasowego kawalerii ${ }^{6}$. W przypadku 1 AK dawano nawet szansę na rehabilitację dezerterom recydywistom.

Motywy dezercji żołnierzy $z$ armii bolszewickiej były różne, nie wszyscy $z$ nich szukali kontaktu $z$ WP. Żołnierzy ukraińskich bardziej interesowały rodzime formacje walczace po stronie polskiej. W końcu kwietnia 1920 r., podczas pomyślnej ofensywy armii Józefa Piłsudskiego i Symona Petlury na Kijów, wojska atamana zasilili ukraińscy żołnierze, którzy służyli w dwóch brygadach 19 Armii Bolszewickiej. Armia tą dowodził litewski komunista Hieronim Uborewicz ${ }^{7}$. Dokonujacy takiego wyboru Ukraińcy zapewne byli świadomi narodowo i politycznie. O wiele większa grupa ukraińskich, białoruskich lub rosyjskich żołnierzy w wojennym chaosie pragnęła jedynie wrócić w rodzinne strony. Mimo intensywnej indoktrynacji większość $z$ nich wciąż nie wiedziała, dlaczego i o co walczy. Najczęściej ciągle głodni żołnierze chłopskiego pochodzenia chcieli przede wszystkim przeżyć ${ }^{8}$. I wrócić do rodzinnej wioski.

Wśród armii bolszewickiej byli także żołnierze, którzy nie decydowali się na powrót w rodzinne strony, tylko dezerterowali na polska stronę. W przypadku dezercji całych jednostek wojskowych takie odziały niemal od razu przystępowały do walki z siłami Armii Czerwonej. Przykładem było przejście 31 maja 1920 r. na polska stronę 600 kozaków z 3 Brygady 14 DK$^{9}$. Zbiegli kozacy pod dowództwem Wadima Jakowlewa walczyli $z$ armią Siemiona Budionnego.

Prawdopodobnie dezercje $z$ Armii Czerwonej, zwłaszcza kozaków $z$ konnej armii Budionnego, byłyby jeszcze większe, gdyby nie propaganda bolszewicka, która przestrzegała swoich żołnierzy przed represjami w Polsce. $Z$ oddziałów czerwonoarmistów docierały sygnały, że chętnych do przejścia na stronę polską nie brakowało. Polski wywiad ustalił, że wielu Kozaków zainteresowanych dezer-

${ }^{6}$ Ibidem, s. 181.

7 A. Za moys ki, Warszawa 1920. Nieudany podbój Europy. Klęska Lenina, Kraków 2009, s. 81.

8 Ibidem, s. 70-71.

9 A. Smoliński, op. cit., s. 161-162. 
cjami do WP było przekonanych, że Polacy nie prowadzą wśród ich formacji wystarczajacej i skutecznej agitacji ${ }^{10}$.

$Z$ usług dezerterów z Armii Czerwonej, którzy wyrazili wolę ponownej walki $z$ bolszewikami w WP, niemal natychmiast korzystano. Zdecydowanie bardziej liczyli się zbiegli oficerowie niż szeregowcy. Bolszewiccy oficerowie dostarczali cennych informacji, często deklarowali natychmiastową służbę polową w WP, dlatego wyprowadzano ich $z$ obozów jenieckich i szybko zaopatrywano w karty tymczasowego pobytu. Otrzymywali je nie tylko oficerowie, lecz także ich rodziny. Dokumenty wystawiano również zbiegłym żonom oficerów Armii Czerwonej. Tylko 26 sierpnia 1920 r. kartę pobytu tymczasowego w Warszawie otrzymał oficer Armii Czerwonej Timofiej Pachomow i jego żona Nina, a także Walentina Szyszkina, żona bolszewickiego oficera, która na stronę polska zbiegła $z$ dziećmi ${ }^{11}$. Szczególna troską objęto bolszewickich oficerów tuż przed rozstrzygnięciem tzw. bitwy warszawskiej. Szef Biura Wywiadowczego 12 sierpnia 1920 r. pisał do Adiutantury Komendy Miasta Warszawy: „5 oficerów Czerwonej Armii, którzy przeszli dobrowolnie na nasza stronę, należy ulokować w lepszym lokalu oraz dać im możliwość napisania listów do kolegów w celach agitacyjnych. Listy te winny być dostarczone na dzień 13-ty sierpnia B.W. Oddz. II Nacz. Dow. WP"12.

W trakcie wojny polsko-bolszewickiej oddziałów nie porzucali tylko bolszewicy. $Z$ wojennego chaosu korzystali także żołnierze ze stacjonującej w Polsce Francuskiej Misji Wojskowej. W marcu 1920 r. o pomoc do naszych władz wojskowych i policyjnych zwróciło się Sąownictwo Francuskiej Misji Wojskowej w Polsce. Na terenie Polski wydano list gończy za Renault Lucyanem, francuskim żołnierzem skazanym na pięcioletnią karę więzienia. Francuski dezerter nie tylko ukrywał się w Krakowie, ale dopuścił się tutaj licznych kradzieży ${ }^{13}$. Nie wiadomo, czy polskiej policji albo

10 Notatka szefa Wydziału IV BW skierowana do Wydziału VI BW dot. agitacji wśród Czerwonoarmistów z 15 X 1920 r., Wojskowe Biuro Historyczne [dalej: WBH], Naczelne Dowództwo Wojska Polskiego [dalej: NDWP], sygn. I.301.8, teczka 338, nlb.

${ }^{11}$ Karty pobytu tymczasowego w Warszawie wystawione dla Timofieja i Niny Pachomowa oraz Walentiny Szyszkiny przez szefa biura wywiadowczego z 26 VIII 1920 r., WBH, NDWP, sygn. 301.8, teczka 489, k. 141-142.

12 Rozkaz do Adiutantury Komendy Miasta Warszawy z 12 VIII 1920 r., WBH, NDWP, sygn. 301.8, teczka 489, k. 130.

13 Pismo kpt. Rozze, Komisarza - Sprawozdawcy Rady Wojennej Francuskiej z 10 III 1920 r., Archiwum Narodowe w Krakowie [dalej: ANK], Komenda Wojewódzka Policji Państwowej w Krakowie [dalej: KWPPK], sygn. 96, nlb. 
żandarmerii udało się zatrzymać Francuza. Lucyan znał Kraków bardzo dobrze. W raportach przypuszczano jednak, że przedostał się do Francji.

Polski wywiad przekonał się, że dezerterzy nie tylko moga być źródłem ważnych informacji wojskowych, opisywali też życie codzienne swojego kraju, a także położenie polskiej ludności cywilnej w krajach ościennych. Warto zwrócić uwagę, że to właśnie zeznania litewskich dezerterów w listopadzie 1920 r. potwierdziły wrogie nastawienie Litwinów do Polaków. Uciekinierzy z litewskiego wojska podkreślali wyjątkowy szowinizm tamtejszych księży: „Nienawiść tę wśród ludzi rozlewają głównie księża, głosząc przy każdej sposobności $z$ ambon, by każdy, czym tylko może, bił Polaków usiłujących zagarnąc ziemię rdzennie litewską"14.

Doświadczenia wyniesione $z$ lat 1919-1920 skłoniły władze polskie do wypracowania odpowiedniego postępowania $z$ dezerterami z państw obcych, którzy znaleźli się w Polsce. Wiosną 1923 r. Ministerstwo Spraw Wewnętrznych (dalej: MSW) wydało dwa ważne dokumenty, które regulowały wspomnianą kwestię. W dniu 31 marca 1923 r. ukazał się okólnik nr 8 dotyczacy postępowania z dezerterami i wojskowymi pozostajacymi w służbie czynnej armii cudzoziemskiej. Tajny dokument dotyczył przede wszystkim uciekinierów $z$ armii sowieckiej i litewskiej. W zależności od celu i charakteru dezercji do Polski wobec zbiegłych żołnierzy przewidywano stosowanie dwóch kategorii: A i B. Kolejną kategorią była C, która nie odnosiła się do dezerterów.

Do kategorii A zaliczano żołnierzy zbiegłych ze swoich oddziałów $z$ powodów politycznych, a także niezadowolonych $z$ przebiegu służby wojskowej. Grupę tę odnoszono de facto do uchodźców, którym grozily represje na terenie swojego kraju, a Polskę wybrali jako miejsce bezpiecznego azylu. Do kategorii B sklasyfikowano tzw. dezerterów pozornych, którzy w rzeczywistości byli wojskowymi szpiegami. Przewidywano, że takie osoby, poza rozpoznaniem wojskowym, będą zajmować się polityczną działalnością wywrotową, komunistyczną agitacją ludności cywilnej lub propaganda wśród wojska i formacji granicznych. Uznawano, że dezerterzy ci sa symulantami, którzy odwracaja od siebie podejrzenia w celu uzyskania pozwolenia na pobyt w Polsce. Kategoria C odnosiła się ściśle do wojskowych $z$ armii litewskiej i sowieckiej, którzy przekroczyli

${ }^{14}$ Odpis formularza zeznań jeńców-dezerterów z armii litewskiej z 12 XI 1920 r., WBH, NDWP, sygn. I.301.8, teczka 338, s. 1. 
granicę polska $z$ bronią (lub bez niej) w celach zbrojnych napadów i rabunków. Byli to członkowie specjalnych komand zbrojnych, którzy nie zdołali powrócić do swej bazy wypadowej ${ }^{15}$.

W dokumencie z 31 marca 1923 r. wskazywano na to, aby każdy przypadek dezercji traktować indywidualnie. Szczególnie wiele wskazówek pojawiało się w rozpatrywaniu kazusów żołnierzy sowieckich i litewskich. MSW nakazywało, by każdy wojskowy z Litwy czy ZSRR, który nie ma dokumentów na pobyt w Polsce, był zatrzymywany. Po ustaleniu danych personalnych dezertera dokładnie go przesłuchiwano. W trakcie dochodzenia ustalano motywy, okoliczności i czas jego przybycia do naszego państwa. W śledztwie starano się dokładnie ustalić, jak litewski lub sowiecki wojskowy zachowywał się w Polsce do chwili jego zatrzymania. Kolejny etap stanowiło przekazanie go do Oddziału II Sztabu Dowództwa Okręgu Korpusu (dalej: DOK) ${ }^{16}$ lub do jego najbliższej ekspozytury. Oficerowie wojskowego wywiadu zbierali wyczerpujace informacje od przesłuchiwanego, ustalali, czy jest on faktycznym dezerterem, czy też, jak pisano, „symulantem”. Dopiero po tym etapie klasyfikowano go do wspomnianych grup: A, B lub $\mathrm{C}^{17}$. Jeśli zbiegły żołnierz z zagranicy był „przydatnym dezerterem”, obiecującym „źródłem informacji”, to kwalifikowano go do kategorii A. Gwarancje pobytu w Polsce dezerter mógł otrzymać także wtedy, kiedy nie potwierdzono, że zagraża bezpieczeństwu państwa. Dopiero w pełni pozytywna i często długa weryfikacja sprawiała, że na terenie II Rzeczypospolitej udzielano mu politycznego azylu.

Wszyscy pseudodezerterzy, którym dowiedziono wrogie zamiary w stosunku do Polski (m.in. rozpoznano dywersyjno-partyzancki charakter ich pobytu), mieli zostać przekazani do obozu internowania w Strzałkowie ${ }^{18}$. Szefostwo tamtejszego obozu nie wiedziało,

15 Tajny Okólnik nr 8 Ministerstwa Spraw Wewnętrznych [dalej: MSW], dot. postępowania $z$ dezerterami i wojskowymi pozostajacymi w służbie czynnej armii cudzoziemskich z 31 III 1923 r., WBH, Samodzielny Referat Informacyjny [dalej: SRI], Dowództwa Okręgu nr V [dalej: DOK V], sygn. I.371.5/A, teczka 265, s. 1-2, k. 151.

${ }^{16}$ Należy również przypomnieć, że od 22 XII 1928 r. O. II. Sztabu Generalnego WP funkcjonował jako O. II. Sztabu Głównego WP [dalej: O II SGWP].

17 Tajny Okólnik nr 8 Ministerstwa Spraw Wewnętrznych, dot. postępowania $z$ dezerterami i wojskowymi pozostajacymi w służbie czynnej armii cudzoziemskich z 31 III 1923 r., WBH, SRI, DOK V, sygn. I.371.5/A, teczka 265, s. 1-2, k. 151 .

18 Ibidem, s. 3, k. 152. 
jak z nimi postępować - dokument MSW stwierdzał jedynie, że władze obozu zostana poinformowane o dalszych instrukcjach w momencie przyjazdu takich osób.

Dokument z 31 marca 1923 r. dotyczył postępowania przede wszystkim $z$ uciekinierami $z$ armii sowieckiej i litewskiej. Dwa tygodnie później ukazał się tajny okólnik nr 9. Pismo urzędowe z 17 kwietnia 1923 r. objęło dezerterów z armii czechosłowackiej, niemieckiej, łotewskiej i rumuńskiej. MSW przypomniało, aby wszystkich zaliczonych do kategorii B i C kierować do obozu dla internowanych w Strzałkowie ${ }^{19}$. Okólnik ten miał wyjątkowe znaczenie jeszcze $z$ jednego powodu - gen. Władysław Sikorski, kierujący w tym czasie MSW, wyodrębnił w nim kategorię dezerterów $z$ obcych armii, których należało wesprzeć. Byli to Polacy, którzy w następstwie Wielkiej Wojny znaleźli się poza obszarem państwa polskiego i zostali wcieleni do armii cudzoziemskich. Sikorski nakazywał zachowywać ostrożność, równocześnie apelował: „Aby nie zrażać do Polski i jej organów wykonawczych ludzi, którzy $z$ pobudek patriotycznych porzucili służbę czynną w armiach cudzoziemskich" 20 .

Nie wiadomo, do ilu Polaków służących w armiach ościennych dotarły słowa Sikorskiego. Wśród dezerterów, którzy porzucili swoje oddziały w Czechosłowacji, Rumunii i Niemczech, nie zabrakło również polskich żołnierzy. Przykładowo: w listopadzie 1924 r. do biura ds. cudzoziemców krakowskiej Dyrekcji Policji Państwowej zgłosił się Józef Rzucidło, dezerter $z$ armii rumuńskiej. Zbiegły żołnierz zatrzymał się w mieszkaniu swojego brata, sierż. sztab. Karola Rzucidły ${ }^{21}$, który służył w krakowskiej wojskowej Zbrojowni nr IV. Jeszcze wcześniej, bo w październiku 1923 r. z oddziału niemieckich kanonierów z Frankfurtu (prawdopodobnie n. Odra) zbiegł szer. Adolf Malcherczyk. Po trzech dniach dotarł na teren rodzinnego Górnego Śląska ${ }^{22}$.

19 Tajny Okólnik nr 9 MSW w sprawie postępowania $z$ dezerterami i wojskowymi pozostającymi w służbie czynnej armii cudzoziemskich z 17 IV 1923 r., WBH, SRI, DOK V, sygn. I.371.5/A, teczka 265, s. 1, k. 153.

20 Ibidem.

${ }^{21}$ Pismo Kier. Ekspozytury Pol. Polit. Policji Państwowej na miasto Kraków dotyczące Józefa Rzucidło - obcokrajowca - dezertera armii rumuńskiej z 20 XII 1924 r., WBH, SRI, DOK V, sygn. I.371.5/A, teczka 265, k. 176.

${ }^{22}$ Spis dezerterów z armii obcej - niemieckiej, Powiatowa Komenda Policji Województwa Śląskiego [dalej: PWŚ] w Rybniku z 13 XII 1923 r., WBH, SRI, DOK V, sygn. I.371.5/A, teczka 265, s. 1, k. 184. 
W pierwszych latach odzyskanej niepodległości polscy żołnierze podążali do ojczyzny także ze Związku Sowieckiego. Najbardziej znanym przypadkiem dezercji z Armii Czerwonej była długo przygotowywana ucieczka Bolesława Kontryma. Okoliczności zbiegostwa Kontryma w grudniu 1922 r. do dzisiaj wzbudzają kontrowersje. Witold Pasek, autor biografii „Żmudzina”, w swojej książce stwierdził, że jego dezercja w ogóle nie została w dokumentach sowieckich zauważona. Pisał również, że Kontrym nigdy nie został w ZSRR zdegradowany i pozbawiony odznaczeń. W opinii Paska również mieszkającej w Związku Sowieckim rodziny „Żmudzina” nigdy nie represjonowano ${ }^{23}$. Jeśli Pasek ma rację, to B. Kontrym nie był de facto dezerterem, tylko szpiegiem. Nie ma jednak żadnych dowodów, aby po przybyciu do Polski prowadził on działalność wywiadowczą na rzecz ZSRR.

Nie wszyscy polscy uciekinierzy $z$ armii czechosłowackiej, niemieckiej, rumuńskiej i sowieckiej kierowali się, jak pisał gen. Sikorski, „pobudkami patriotycznymi”. W niektórych przypadkach zbiegostwo Polaków $\mathrm{z}$ oddziałów cudzoziemskich było najlepszym sposobem na uniknięcie odpowiedzialności karnej. Tego typu powroty też odnotowywano. Dla majacych kłopoty z prawem korzystanie z możliwości, jakie stwarzał Polakom służącym w obcych armiach okólnik nr 9, było sytuacją wręcz wymarzoną. $Z$ „patriotycznej oferty", która zakładała szczególna pomoc dezerterom z polską deklaracją narodowościowa, skwapliwie skorzystał m.in. Alojzy Szkowron. Żołnierz ten służył w czechosłowackim 34 pułku piechoty (dalej: pp) w Opawie, skąd zdezerterował w listopadzie 1922 r. Szkowron ukrywał się blisko dwa lata. Dnia 12 sierpnia 1924 r. zgłosił się po stronie polskiej, prawdopodobnie w Cieszynie. Wkrótce podjął pracę w cieszyńskiej fabryce zegarków i, jak opiniowała policja, zachowywał się lojalnie, starajac się o polskie obywatelstwo ${ }^{24}$. W $1925 \mathrm{r}$. uzyskał je i poczuł się wyjątkowo pewnie. Coraz mniej interesowała go praca, a coraz bardziej łatwy i szybki zarobek. W lutym $1928 \mathrm{r}$. $z$ miejsca zatrudnienia, gdzie pracował od 14 dni, ukradł 277 zł. Po tym wydarzeniu wrócił do macierzystego pułku w Opawie. Władze wojskowe Czechosłowacji dały mu szansę, ale nie docenił tej wielkoduszności. W dniu 19 marca 1928 r. ponownie zbiegł z 34 pp.

${ }^{23}$ W. Pasek, „Żmudzin” Bolesław Kontrym 1898-1953, Warszawa 2006, s. $22-24$.

${ }^{24}$ Wykaz dezerterów obcych armii, Komisariat PWŚ w Cieszynie $z 30$ IX 1924 r., WBH, SRI, DOK V, sygn. I.371.5/A, teczka 265, s. 1, k. 188. 
Nie cieszył się długo wolnością. Po kilku dniach w czeskim Cieszynie aresztowała go czechosłowacka żandarmeria. Został osadzony w wojskowym więzieniu w Ołomuńcu ${ }^{25}$. Warto dodać, że Szkowron, majac polskie obywatelstwo, nie stracił czechosłowackiego.

Niektórzy Polacy uciekajacy ze służby w obcych armiach podawali niedokładne informacje, a także konfabulowali. Zdarzało się, że dezerterzy zmieniali swoje zeznania, spisywano $z$ nimi nie jeden, a kilka protokołów. Sytuację zbiegłych Polaków ze Wschodu dodatkowo komplikowała niedawna wojna polsko-rosyjska. Nawet kilka lat po niej trudno było dociec prawdy, ocenić obiektywnie, czy ma się do czynienia $z$ bohaterskim dezerterem, dzielnym uciekinierem $z$ Armii Czerwonej, czy też $z$ umiejętnie zacierającym swoją niechlubna, kryminalna przeszłość w Rosji bolszewickiej uciekinierem. Po spisaniu protokołu w krakowskiej siedzibie Samodzielnego Referatu Informacyjnego (dalej: SRI) wciąż nie było wiadomo, czy urodzony w Jedliczu Grzegorz Wojnar to zbiegły polski patriota z Armii Czerwonej, czy też pospolity złodziej albo gorliwy zwolennik komunizmu ${ }^{26}$. Wojnar przerywał, a także zmieniał swoje zeznania. Niewykluczone, że nawet to, co zaprotokołowano, wynikało $z$ presji przesłuchujących, a nie stanowiło faktycznych przeżyć Wojnara.

W tajnych okólnikach z 31 marca i 17 kwietnia 1923 r. nie przewidziano właściwego postępowania wobec takich dezerterów, jak przytoczony Szkowron. W okólnikach nr 8 i 9 nic nie napisano o uciekinierach pochodzacych $z$ armii innych niż czechosłowacka, łotewska, litewska, niemiecka, sowiecka i rumuńska. W latach dwudziestych i trzydziestych wśród wojskowych zbiegów byli także Francuzi i Węgrzy. Dnia 9 sierpnia 1922 r. $z$ francuskiego 10 baonu strzelców rezerwy, który w tym czasie jeszcze stacjonował na Górnym Śląsku, zdezerterował Juliusz Puera. Francuski batalion wchodził w skład wojsk okupacyjnych, które zostały podporząkowane Naczelnemu Dowództwu Wojsk Sprzymierzonych na Górnym Śląsku. Puera urodził się w Calais, prawdopodobnie w rodzinie

${ }^{25}$ Pismo Komisariatu PWŚ z 17 VI 1928 r., WBH, SRI, DOK V, sygn. I.371.5/A, teczka 265, s. 1, k. 179.

${ }^{26}$ Protokół spisany z Grzegorzem Wojnarem w siedzibie SRI, DOK V w Krakowie z 4 II 1926 r., WBH, SRI, DOK V, sygn. 371.5/A, teczka 263, s. 1-3, k. 313-314. SRI powstały w 1924 r. z przekształcenia Wydziałów Informacyjnych DOK. Były terenowymi komórkami służby kontrwywiadowczej. O SRI pisali m.in. A. Misiuk, Służby specjalne II Rzeczypospolitej, Warszawa 1998; A. Pepłoński, Kontrwywiad Drugiej Rzeczypospolitej, Warszawa 2002. 
polskich emigrantów, od kwietnia 1920 r. służył we francuskim $127 \mathrm{pp}^{27}$. Na Górnym Śląsku odnalazł się dość dobrze. Nic nie wiadomo, czy przeszedł jakakolwiek weryfikację. Nie aresztowano go ani nie przekazano stronie francuskiej. Puera sumiennie pracował jako robotnik w jednej $z$ firm w Nowym Bytomiu. Jego tajny policyjny nadzór opiniował, że pod względem politycznym i moralnym prowadził się dobrze ${ }^{28}$.

Świadectwa wzorowej moralności nie można było wystawić Jeanowi Genetowi. Ten w przyszłości słynny francuski pisarz, 18 czerwca 1936 r. uciekł z 2 pułku piechoty morskiej, który w latach 19301939 stacjonował w garnizonie Brest ${ }^{29}$. Genet, wędrując po różnych krajach Europy, jeszcze w 1936 r. przedostał się z Czechosłowacji do Polski. Już drugiego dnia po przyjeździe do Katowic Genet, wraz z pochodzącym z Brna Michaelisem Andričem, został aresztowany. Powodem zatrzymania było rozprowadzanie fałszywych pieniędzy ${ }^{30}$. Po powrocie do Francji Genet staną został zatrzymany, a 13 stycznia 1938 r. sad wojskowy w Marsylii skazał go za dezercję, podkreślając „zaburzenia psychiczne i amoralność” oskarżonego ${ }^{31}$. Uwagi sądu dotyczyły nieskrępowanego i jawnie deklarowanego homoseksualizmu Geneta. Z więzienia zwolniono go w 1944 r.

Trudno powiedzieć, jak potoczyły się koleje życia żołnierzy węgierskich, których ujęto w karpackich placówkach granicznych. Dnia 7 stycznia 1937 r. w Beskidzie Niskim, między Gorlicami i Muszyna zatrzymano Jozefa Polewko, dezertera z 7 pułku artylerii (dalej: PA) w Miszkolcu ${ }^{32}$. Kilka miesięcy później, 25 maja 1937 r., Straż Graniczna $z$ placówki w Radoszycach ujęła szer. Janosza Bałasza. Węgierski żołnierz pochodzacy z miasta Szatorali zbiegł z 2 pułku ochrony pogranicza. Jak zeznał w śledztwie Bałasz, $\mathrm{w}$ swojej jednostce obawiał się kary, dlatego rejterował. $Z$ Węgier na terytorium Polski przywędrował pieszo, zajęło mu to sześć dni.

27 Wykaz dezerterów obcych armii z 6 VIII 1923 r., WBH, SRI, DOK V, sygn. I.371.5/A, teczka 265, s. 1, k. 192.

28 Ibidem.

${ }^{29}$ L. Dattas, Cnotliwy żywot Jeana Geneta, przekł. K. Kot, Warszawa 2009, s. 103 .

${ }^{30}$ J. Ge net, Dziennik złodzieja, przekł. P. Kamiński, Kraków 2004, s. 74.

${ }^{31}$ L. Dattas, op. cit., s. 107-108.

${ }^{32}$ Komunikat Informacyjny nr 1/37 za czas od 1 do 31011937 roku, z 8 III 1937 r., Archiwum Straży Granicznej w Szczecinie [dalej: ASG], Straż Graniczna 1928-1939 [dalej: SG], Komenda Straży Granicznej [dalej: KSG], sygn. 187/138, s. 7, k. 8 . 
Na Słowacji nikt go nie zatrzymywał ${ }^{33}$. Został przekazany polskiej placówce w Komańczy. O jego dalszych losach nic nie wiadomo.

Postępowanie wobec dezerterów $z$ innych państw, którzy schronili się w Polsce, nigdy nie zostało skutecznie uregulowane. W polskim prawie sformułowania zwiazane $z$ poborem były nieprecyzyjne. Do polskiej armii teoretycznie mogły być powołane osoby, które unikały w swoich ojczystych krajach służby wojskowej. W przypadku braku dokumentacji potwierdzającej, że sa obcokrajowcami, musiały się liczyć z mobilizacją. Do takich przypadków zresztą dochodziło w latach trzydziestych ${ }^{34}$. Polskie sady wojskowe rozpatrywały np. odwołania Polaków z amerykańskim obywatelstwem, którzy zostali wcieleni do WP.

Brak jasnych i precyzyjnych zapisów, jak postępować z dezerterami uchodzacymi $z$ innych krajów do Polski, miał kilka przyczyn. Do najważniejszych należała duża nieufność wobec takich osób w polskich kręgach wojskowych. Krytyczne stanowisko w tej sprawie zajmował O. II. Sztabu Generalnego (Głównego) WP (dalej: O. II. SGWP). Już w 1923 r. polski wywiad zakładał, że w razie konfliktu zbrojnego dezerterzy $z$ państw obcych stana się niebezpiecznym dywersyjnym zapleczem. $Z$ obawa pisano o tym do MSW: „Dezerterzy wojsk państw ościennych, zbiegli na terytorium Polski, $z$ punktu widzenia wywiadu wojskowego, stanowia element $\mathrm{w}$ wysokim stopniu niepewny (podatny na szpiegostwo i dywersji nieprzyjacielskiej), a co za tym idzie kwalifikujący się na czas wojny do osadzenia w obozach internowania" 35 .

Czujność polskich służb na początku lat dwudziestych była uzasadniona. Dotyczyło to szczególnie granicy z ZSRR. Wschodnie rubieże państwa polskiego w 1923 r. nie należały do bezpiecznych. Dochodziło tutaj do różnych incydentów, na teren Polski wciąż przenikały uzbrojone grupy. W związku $z$ tym weryfikowano wszystkie tropy i poszlaki, jakiekolwiek sygnały o dezerterach z Armii Czerwonej budziły podejrzenia. W toku śledztwa sprawdzano, czy uciekinierzy nie sa szpiegami, prowokatorami lub dywersantami destabilizującymi sytuację Rzeczypospolitej.

${ }^{33}$ Komunikat Informacyjny $\mathrm{nr} 5 / 37$ za czas od 1 do $31 \mathrm{~V} 1937$ r. z 25 VI 1937 r. ASG, SG 1928-1939, KSG, sygn. 187/138, s. 10.

${ }_{34}$ Mgr por. k.s. L. Milewski, Dezercja cudzoziemca, „Wojskowy Przegląd Prawniczy" 1936, R. IX, nr 2, s. 39-44.

35 Pismo Szefa Oddziału II Sztabu Generalnego [dalej: O. II. Szt. Gł.] do MSW (Wydziału Bezpieczeństwa Publicznego) z 12 VII 1923 r., WBH, SRI, DOK V, sygn. I.371.5/A, teczka 265, s. 1, k. 188. 
Wywiadowczy komunikat o tzw. fałszywych polskich dezerterach z Armii Czerwonej odebrano w lipcu 1926 r. Tego rodzaju agenci, jak pisano $\mathrm{w}$ jednym $z$ materiałów operacyjnych, mieli przeniknąc do Polski w momencie przejęcia władzy przez Piłsudskiego. Powrót do życia politycznego Marszałka władze sowieckie miały uznać za szczególne zagrożenie dla obronności ZSRR. Polscy wywiadowcy ostrzegali, że w Moskwie zaplanowano wyszkolenie specjalnego oddziału pozornych dezerterów. Tak zwani polscy patrioci mieli „uciec” z sowieckiej armii na teren Polski. Akcja miała mieć charakter długofalowy. Specjalne komando sowieckie nie obowiazywał w Polsce pośpiech. Na początku położono nacisk na uwiarygodnienie i dezinformacje. Pierwszym zadaniem stało się oszukanie polskiego wywiadu podczas nieuniknionego przesłuchania. Pozorni dezerterzy w trakcie przesłuchania mieli przede wszystkim minimalizować siłę i możliwości bojowe sowieckiej armii. Wywiad wojskowy w głębi kraju miał nastąpić później. Aby konspiracja była skuteczna, zabroniono im nawiązywania jakiejkolwiek współpracy z polskimi komunistami. Szpiegowskie komando nawet $\mathrm{w}$ czasie ewentualnej wojny polsko-sowieckiej miało oficjalnie popierać polska stronę. Nawet wtedy obowiazywał ich stanowczy zakaz powrotu do ZSRR ${ }^{36}$. Informacja o specjalnej grupie fikcyjnych dezerterów $z$ armii sowieckiej wywołała alarm w niektórych częściach Polski. Tylko w sierpniu 1926 r. komendy powiatowe jednostki policji w Chełmnie i Kościerzynie zameldowały komendzie wojewódzkiej policji w Toruniu, że na podległym terenie wojskowi uciekinierzy $z$ ZSRR nie zostali wykryci ${ }^{37}$. Niestety na temat specjalnej sowieckiej grupy brakuje innych źródeł. Nie ma pewności, czy rzeczywiście ją powołano.

Być może strona polska dokonała fałszywego rozpoznania w wyniku celowych działań kontrwywiadu sowieckiego. Tym bardziej że, jak pisał Mariusz Wołos, właśnie w 1926 r. agenci Moskwy mieli dostęp do wielu ważnych informacji w Toruniu, włączywszy w to te, którymi dysponowała miejscowa Komenda Wojewódzka Policji Państwowej ${ }^{38}$.

${ }^{36}$ Tajne pismo dot. dezerterów z armii sowieckiej z 3 VII 1926 r., Archiwum Państwowe w Bydgoszczy [dalej: APB], Komenda Wojewódzka Policji Państwowej w Toruniu [dalej: KWPPT], sygn. 157, k. 422.

${ }^{37}$ Informacje dotyczacce dezerterów $z$ armii sowieckiej z 5 VIII 1926 r. i 17 VIII 1926 r., APB, KWPPT, sygn. 157, k. 416, 420.

${ }^{38}$ M. Woło s, O Piłsudskim, Dmowskim i zamachu majowym. Dyplomacja sowiecka wobec Polski w okresie kryzysu politycznego 1925-1926, Kraków 2013, s. 234. 
Niewykluczone jednak, że w 1926 r. specjalne komando pozornych dezerterów w Polsce rzeczywiście się pojawiło, a prowincjonalne jednostki policji $z$ województwa pomorskiego nie wykazały pełnego zaangażowania, aby wykryć i zlikwidować taką grupę. Współpraca O. II. SGWP i policji nie zawsze i nie wszędzie dobrze funkcjonowała. O wadliwym współdziałaniu świadczyło pismo skierowane przez SRI przy DOK II do O. II. SGWP w Warszawie. Komórka informacji wojskowej w Lublinie konstatowała, że tutejsze jednostki policji nieudanie wypełniaja swoje obowiązki, wołyńska policja miała bagatelizować zagrożenia. Ekspozytura SRI przy DOK wskazywała, że przyłapani szpiedzy z ZSRR byli przez tutejszą policję po kilku tygodniach $z$ powrotem odsyłani do Związku Sowieckiego (sic!). Wojskowy wywiad zarzucał tutejszej policji brak skuteczności i działanie jedynie dla publicznego poklasku ${ }^{39}$.

Z dzisiejszej perspektywy pewne jest, że Rozwiedupr-Razwiedywatielnoje Uprawlenie, czyli Zarząd Wywiadowczy Sztabu Armii Czerwonej, działał intensywnie i na wielu płaszczyznach. W działaniach operacyjnych przeciwko polskiej armii sowiecki wywiad wykorzystywał różne środowiska: od werbunku służby domowej polskich oficerów, przez jeńców z byłej armii austriacko-węgierskiej, na pozyskiwaniu polskich wojskowych skończywszy. Tylko w 1933 r. kontrwywiad Korpusu Ochrony Pogranicza (dalej: KOP) rozpracował w Polsce 195 agentów sowieckich, a rok później aż $232^{40}$. Nie jest to jednak ostateczna liczba, ponieważ szpiegostwo radzieckie rozpracowywały także wszystkie SRI.

W WP szybko przekonano się, że na dezerterów z Armii Czerwonej, którzy otrzymali szansę służby w polskiej armii, nie można liczyć. Najlepszym przykładem było przyjęcie do WP Daniela vel Donata Budniaka, który w 1920 r. dwukrotnie uciekał z bolszewickiego wojska. W 1921 r. przedarł się do Polski, a rok później w czerwcu został wcielony do $85 \mathrm{pp}$, gdzie po miesiącu skierowano go jako pisarza do Powiatowej Komendy Uzupełnień (dalej: PKU) w Głębokim. Niestety nie okazał się dobrym żołnierzem. Budniak pracując w komendzie uzupełnień, dopuszczał się nadużyć, m.in.

${ }^{39}$ Odpis ściśle tajnego pisma SRI, DOK nr II do O. II. SGWP. dot. współpracy organów policji z tut. wywiadem z 9 X 1926, Archiwum Akt Nowych [dalej: AAN], Urząd Wojewódzki w Wołyniu [dalej: UWW], sygn. 979/53, s. 2-3.

${ }^{40}$ H. Ćwięk, Działalność wywiadu sowieckiego na polskim pograniczu $w$ latach trzydziestych, Warszawa 1995, s. 85. Należy dodać, że poza Razwieduprem działalność szpiegowska na ternie Polski prowadził także Innostrannyj Otdieł - INO, WCzKa, potem GPU i OGPU. 
dostarczając osobiście książeczek wojskowych do mieszkań wybranym osobom i żądając w zamian za to wódki bądź pieniędzy. $Z$ taką reputacja nie pełnił zbyt długo funkcji pisarza PKU w Głębokim. Pod koniec grudnia 1923 r. ratował się ucieczka do ZSRR, gdzie trafił do więzienia na sześć miesięcy jeszcze za dezercję $z$ Armii Czerwonej w 1920 r. Do Polski powrócił w maju 1933 r., ale wtedy nie było już wątpliwości, że przybył do Polski z misją szpiegowską. Został więc szybko zatrzymany i osądzony. Wojskowy Sąd Okręgowy (dalej: WSO) nr III w Wilnie 6 lutego 1934 r. skazał go na kare trzech lat i sześciu miesięcy pozbawienia wolności ${ }^{41}$.

Pomyłki $z$ pozornymi dezerterami nie dotyczyły tylko zbiegów z Armii Czerwonej. W rolę zbiegłego żołnierza $z$ czechosłowackich wojsk lotniczych wcielił się w kwietniu 1925 r. Ladislav Vattay. Czeski szpieg, pod płaszczykiem dezertera z czechosłowackiej armii usiłował uzyskać zgodę na służbę w krakowskim 2 Pułku Lotniczym (dalej: 2 PL). Przez kilka dni nawet przebywał w koszarach na terenie krakowskiego lotniska. Jego ciekawość na lotnisku Rakowice-Czyżyny szybko wzbudziła podejrzenia. Po zatrzymaniu i przesłuchaniu Vattay przyznał się do swoich faktycznych powodów „dezercji” do Polski. Wyrokiem Okręgowego Sądu w Krakowie 3 października 1925 r. został skazany na dwa lata ciężkiego więzienia $^{42}$. Po odbyciu kary miał zostać, jako obcokrajowiec, natychmiast wydalony $z$ Polski.

Krytyczny stosunek polskiego wywiadu do dezerterów nie zmienił się w kolejnych latach. O. II. SGWP co prawda nie obawiał się zbytnio, że w razie wojny dezerterzy z zagranicy, którzy pozostali $\mathrm{w}$ Polsce, staną się V kolumną. Niepokoiło co innego. Powróciło wciąż retoryczne pytanie o weryfikacje pozyskiwanych od dezerterów informacji. Przypuszczano, że duża część wiadomości ma celowy, dezinformacyjny charakter. Na tego rodzaju problem zwrócił uwage ppłk dypl. Kazimierz Banach. W książce Zasady i metoda pracy Oddziału II Sztabu pisał: „Należy pamiętać o jednej przestrodze: zbiegowie moga być nasłani przez nieprzyjaciela, jednak ogólnie biorąc, mogą dostarczyć bardzo wielu wiadomości nieraz

${ }^{41}$ Wyrok w Imieniu Rzeczypospolitej Polskiej WSO nr III w Wilnie Ko 397/33 z 6 II 1934 r., WBH, Akta Spraw Sądów i Prokuratur Wojskowych [dalej: ASSPW], sygn. I.351.33, teczka 213, s. 1-9.

42 Odpis pisma do Prokuratury przy Sązie Okręgowym z 26 I 1926 r., WBH, SRI, DOK V, sygn. 371.5/A, teczka 233, k. 352; Wyrok w Imieniu Rzeczypospolitej Polskiej przeciwko Ladislavovi Vattayowi z 3 X 1925 r., sygn. 371.5/A, teczka 233, k. 356-358. 
umyślnie zbieranych, żeby zaskarbić sobie przychylność przeciwnika po dostaniu się do niewoli" ${ }^{43}$. $Z$ drugiej strony pułkownik Banach w swoich rozważaniach sugerował, że nigdy nie wolno lekceważyć „ludzkiego źródła” informacji. W realiach wojennych uważał wręcz, $\dot{z}$ e ignorowanie, pomijanie i niepodejmowanie weryfikacji każdej, nawet $z$ pozoru błahej wiadomości zasługuje na wykroczenie ${ }^{44}$. Dlatego też, mimo wielu zastrzeżeń, polski wywiad zazwyczaj nie bagatelizował relacji dezerterów.

Szczególnie ceniono relacje zbiegów, którzy doświadczyli fizycznej i psychicznej przemocy w armii. Prześladowani dezerterzy chętnie i wyczerpujacco opowiadali o strukturze, wyżywieniu, dyslokacji i żołdzie w macierzystych jednostkach. Łamanie tajemnicy wojskowej stawało się osobistą zemstą, swoistą rekompensatą za doznane krzywdy. Takim wartościowym i „użytecznym” dezerterem okazał się m.in. Wistaw Hilel. Ten żydowski żołnierz zbiegł $z$ litewskiego 8 pp. Jego były pułk stacjonował w litewskim mieście Szawle. Hilel był inteligentem, władał jidysz, hebrajskim, angielskim, francuskim i niemieckim. Co ciekawe, bardzo słabo znał język litewski. Studiując na paryskiej Sorbonie, w 1932 r. uzyskał tyłu doktora medycyny. W 1934 r. powrócił na Litwę, gdzie w październiku powołano go do służby wojskowej we wspomnianym pułku. W czerwcu $1935 \mathrm{r}$. został ukarany 20-dniowym aresztem. Powodem uwięzienia było publiczne wygłoszenie poglądu, że Litwa wobec kryzysu związanego z Kłajpedą powinna połączyć swoje siły z Polska przeciwko Niem$\mathrm{com}^{45}$. Hilel przypuszczał, że wkrótce spotkaja go dalsze represje, dlatego zbiegł do Polski. Na terenie Rzeczypospolitej zatrzymano

${ }^{43}$ K. Banach, Zasady i metoda pracy Oddziału II Sztabu, Warszawa 1938, s. 41. W październiku 1937 r. płk Kazimierz Banach chwalony i uznany przez przełożonych za bardzo zdolnego oficera został skierowany do pracy w O. II. SGWP, obejmując stanowisko szefa wydz. IV (Studiów i Ewidencji), w którego skład wchodził m.in. Samodz. Referat „Rosja” i Samodz. Referat „Niemcy”. Po roku pracy ppłk Banacha komplementował szef O. II. SGWP płk Tadeusz Pełczyński, podkreślając, że szef wydz. IV świetnie nadaje się na $z$-cę szefa O. II. SGWP. Ppłk K. Banach w poprzednich latach nie miał jednak żadnego doświadczenia kontrwywiadowczego. Wiosną 1939 r. należał również do grupy oficerów wywiadu, którzy uznawali, że ZSRR w chwili konfliktu Polski z Niemcami pozostanie neutralny - por. T. Dubicki, A. Suchcitz, Oficerowie wywiadu WP i PSZ w latach 1939-1945, t. II (Słownik biograficzny), Warszawa 2011, s. 11-13.

${ }^{44} \mathrm{~K}$. Ban ach, Służba informacyjna $w$ pułku piechoty $w$ czasie wojny, Warszawa 1936 , s. 80.

45 Odpis meldunku kierownika SRI, DOK z 20 V 1936, ASG, KOP, Dowództwo Korpusu Ochrony Pogranicza [dalej: DKOP], sygn. 177/277, s. 1-5, k. 1-6. 
go pod koniec lutego 1936 r., 1 marca osadzono go więzieniu śledczym w Chełmie. Tutaj został przesłuchany przez pracownika SRI. Hilel scharakteryzował najważniejszy skład personalny 3 litewskiej dywizji, opowiedział też o warunkach żywieniowych i stawkach żołnierskich żołdów. Przedstawił dyslokacje dużej części litewskich pułków w Kiejdanach, Kownie i innych miastach. W miarę swojej wiedzy opowiedział o rodzajach rozmieszczonych wojsk i ich wyposażeniu. Na niektóre pytania nie był w stanie odpowiedzieć, co wcale nie zdyskredytowało go w oczach przesłuchującego, wręcz przeciwnie, taka postawa jedynie uwiarygodniała relację przesłuchiwanego. Jeszcze przed przesłuchaniem w SRI uznano, że nie jest on szpiegiem, tylko autentycznym zbiegiem. Chełmski sędzia oświadczył, że zbiegowi przysługuje amnestia i może on być zwolniony od kary za nielegalne przekroczenie polsko-litewskiej granicy ${ }^{46}$.

Hilel nie był jedyny spośród dezerterów obcych armii, którzy zbiegli do Polski i twierdzili, że byli represjonowani. Różnego rodzaju szykany jako przyczynę ucieczki $z$ wojska podawali przekraczający polska granicę żołnierze $z$ Litwy, Czechosłowacji, Rumunii, Niemiec i przede wszystkim ze Zwiąku Sowieckiego. $Z$ tego ostatniego kraju do Polski, mimo dużych trudności, w latach 1918-1939 uciekła najprawdopodobniej największa liczba żołnierzy. Ogromnym problem w ZSRR były również samowolne oddalenia się z jednostek wojskowych i zbiegostwo wewnętrzne.

W latach 1918-1920 dezercje w Armii Czerwonej miały charakter masowy. Jak pisał Aleksander Smoliński, w siłach zbrojnych przyszłego Zwiazku Sowieckiego od stycznia 1919 do czerwca 1920 r. liczba dezercji wyniosła aż 2600000 żołnierzy (sic!). Rekordowy pod tym względem był rok 1919, kiedy zbiegostwo $z$ oddziałów Armii Czerwonej osiagnęło liczbę aż 1761000 żołnierzy. Tylko w guberni charkowskiej w listopadzie 1920 r. stwierdzono ukrywanie się około 100-tysięcznej grupy dezerterów. Duża część $z$ nich dopuszczała się dezercji wcześniej. Pewna liczba dezerterów, jak i osób niestawiających się do poboru, dekowała się w różnych instytucjach państwowych (biura, kolej). Na skutek wojny domowej, a potem zbrojnych zmagań z Polska, także powszechnego chaosu towarzyszacego budowie nowego, komunistycznego państwa w latach 1918-1920 dochodziło również do sytuacji, kiedy zbiegłych dezerterów $z$ pułków wojskowych wcielano do innych. W gronie dezerterów nie brakowało komunistów, a nawet partyj-

${ }^{46}$ Ibidem. 
nych sekretarzy. W marcu 1921 r. wśród ośmiu zbiegłych komunistów z 8 Dywizji Kawalerii Czerwonego Kozactwa znajdował się sekretarz dywizyjnej komórki WKP(b) oraz funkcjonariusz dywizyjnego Oddziału Politycznego ${ }^{47}$. Z dezercjami w Rosji bolszewickiej próbowano walczyć różnymi metodami: od działalności opisanej wcześniej CTK ds. WD po stosowanie odpowiedzialności zbiorowej. Największy spadek dezercji w tym kraju osiagnnięto jednak $z$ innych przyczyn. Od 1921 r. następowało umacnianie nowej władzy, która mogła zapewnić lepsze warunki bytowe żołnierzom. Komuniści coraz bardziej podporząlkowali sobie krnąbrną wieś, na której ukrywali się zbiedzy i gdzie istniało też największe niestawiennictwo do wojskowego poboru.

W 1921 r. w sowieckiej armii doliczono się jeszcze 231 tysięcy dezercji, jednak w 1922 r. ich liczba gwałtownie spadła. Zanotowano wtedy dokładnie 112224 przypadki ucieczki z armii. Ograniczenie dezercji miało też związek $z$ bezlitosnym stosowaniem kar wobec winnych takich przestępstw. Służba wojskowa okazywała się również jedyna szansa powrotu do komunistycznego społeczeństwa przedstawicieli byłej „burżuazji”. Niepewny i wrogi element sprzed rewolucji mógł tylko przez gorliwą służbę ZSRR odkupić swoje winy i wyrazić poparcie dla nowej władzy. O ile dezercje $z$ wojska znikały, o tyle system korupcyjny w nowych realiach ustrojowych miał się dobrze. W zamian za zwolnienie $z$ wojska członkowie komisji wojskowych otrzymywali pieniądze, deficytowe produkty i zawsze pożądany samogon. Gwarancją uniknięcia służby wojskowej było wykupienie u członków komisji wojskowej tzw. białego biletu. Oczywiście wszystko zależało od regionu i składu komisji, a przede wszystkim od zasobności materialnej rekruta albo jego rodziców ${ }^{48}$.

Nie każdą ucieczkę w Armii Czerwonej kwalifikowano jako dezercję, niektóre interpretowano jako samowolne oddalenia się. Kwalifikacja czynu zależała od dowódcy, choć w dużej mierze zagadnienia te uregulował kodeks karny z 1926 r. Dezercje w Armii Czerwonej nie ustały nawet w czasie rządów Józefa Stalina. Mimo wzmocnienia dyscypliny, atmosfery strachu i wzajemnej nieufności problem istniał nadal. W pierwszej połowie 1940 r. było 3543 dezercji i 57321

${ }^{47}$ A. Smolinnski, Dezercje z Robotniczo-Chłopskiej Armii Czerwonej w latach 1918-1922. Wojna z Polska i wojna domowa $w$ Rosji, „Przeglad Wschodni” 2007, t. X, z. 3 (39), s. 691, 694, 709-710.

${ }^{48}$ J.F. Krinko, Hużje Wraga. Djezjerstwo w ZSRR nakanunje i w gody Wjelikoj Otwjeczjestwjennoj wojny w: Istorija i Istoriki $w$ kontjekstje Wrjemjeni, „Naucznyj Żurnal" [Moskwa] 2011, z. 8, s. 91-92. 
tzw. samowolnych oddaleń; w drugiej połowie tegoż roku zarejestrowano 3273 przypadki dezercji i 20429 samowolnych oddaleñ ${ }^{49}$.

O problemie dezercji w Armii Czerwonej zrobiło się szczególnie głośno w trakcie walk w Mandżurii. Apogeum zbiegostwa nastapiło zwłaszcza po japońsko-sowieckiej bitwie, jaka rozegrała się w sierpniu 1938 r. w rejonie Cznang Kuo Feng. Podczas bitwy doszło do kilkudziesięciu przypadków ucieczek na japońską stronę $z$ bronią w ręku. W zbiegostwie licznie uczestniczyli także podoficerowie i oficerowie. Polska prasa sugerowała, że zbiegostwo żołnierzy sowieckich przyczyniło się do ustępstw politycznych ZSRR na rzecz Japonii: „Jak twierdza w moskiewskich kołach politycznych, doniesienia o dezercjach i braku bojowego ducha wśród żołnierzy dowódców armii czerwonej na Dalekim Wschodzie podziałały deprymująco na Kremlu, co miało wywrzeć decydujaccy wpływ na okazanie przez komisarza Litwinowa podczas ostatniego spotkania $z$ ambasadorem Szigemistu daleko idącej ustępliwości i doprowadziło zreszta do zawarcia układu o zawieszeniu broni" ${ }^{50}$.

Z zachowanej dokumentacji KOP wynika, że tylko w latach 1929-1933 odnotowano kilkanaście różnych przypadków dezercji żołnierzy sowieckich. Najczęściej dokonywali tego tamtejsi strażnicy graniczni. W listopadzie 1929 r. polski batalion KOP na pododcinku Mińsk 4/6 zatrzymał szeregowego Grigorija Orykowa z sowieckiej komendantury w Nowym Polu ${ }^{51}$. Tylko w maju 1930 r. do Polski przedostali się szer. Piotr Torunów (ze strażnicy numer 10 21 oddziału pogranicznego), szer. Iwan Kurenbin (z 20 oddziału pogranicznego w Sławucie) oraz Stefan Cwełow. W czerwcu 1933 r. polscy funkcjonariusze KOP zatrzymali szer. Grigorija Furażkina, który pełnił służbę w 21 oddziale sowieckiej straży granicznej w Zastawie-Kamionka, a także szer. Michaiła Niemukowa. Część z żołnierzy, jak Niemukow, dostała się na polska stronę bez uzbrojenia i wyposażenia. Pozostali, jak Konstanty Giergiewicz, trafili do Polski $z$ karabinami, uzbrojeniem i w pełnym umundurowaniu.

Każdy ze zbiegłych pograniczników wymienił inne motywy ucieczki. Torunów twierdził, że decyzję podją po tym, jak otrzymał list od swojej żony, w którym żaliła się, że władze sowieckie w ich rodzin-

\footnotetext{
${ }^{49}$ Ibidem.

50 Dezercje żołnierzy czerwonych skłonity Litwinowa do ustepstw wobec Japonii, „Ostatnie Wiadomości Poranne” 1938, R. I (VII), nr 73 (226), s. 1.

${ }^{51}$ Meldunek plutonu przy brygadzie "Nowogródek” Dywizjonu Żandarmerii [dalej: DŻ] z 30 XI 1929 r., ASG, KOP, Dowództwo Dywizjonu Żandarmerii [dalej: DDŻ], sygn. 178/110, k. 36.
} 
nej miejscowości konfiskują wszystko, co jest im przydatne. Pochodzący $z$ Uralu żołnierz dodał też, że niemal cały czas prześladowali go inni żołnierze. $Z$ tym większą uwaga polscy śledczy przyjęli relacje rozgoryczonego żołnierza o składzie personalnym jego byłej strażni$\mathrm{cy}^{52}$. Kurenbin, również pochodzący $z$ Uralu, $z$ guberni permskiej, do wojska miał wstapić jako ochotnik, ale służba go rozczarowała. Dola szeregowego miała być tylko przejściowa. Służba wojskowa nie spełniła ambicji Kurenbina. Sowiecki żołnierz nie został skierowany na kurs dowódczy. Właśnie na to jako ochotnik ogromnie liczył. Rozczarowany niespełnionymi marzeniami o wojskowej karierze uciekł, jak zeznał, do Polski ${ }^{53}$. Każdy awans w sowieckim wojsku polepszał dotychczasowy byt żołnierza. Nie było to łatwe osiagnięcie, kandydaci do oficerskiej szkoły w ZSRR mieli trudne zadanie. Wstępna selekcja wykluczała osoby niepewne politycznie i faworyzowała proletariuszy. Jak słusznie zauważył podróżujący po Związku Sowieckim w 1932 r. Antoni Słonimski: „Armia w sowietach jest ogromnym spasionym pasożytem na ciele ubogiego narodu" ${ }^{44}$. Status szeregowego nie oznaczał w Armii Czerwonej żadnych przywilejów, to oficerskie pagony podnosiły stopę życia.

Poza niespełnionymi aspiracjami, złymi warunkami służby dezercje sowieckich żołnierzy ze straży granicznej wynikały $z$ trudów codziennego, cywilnego życia w ZSRR. Poczucie wielkiej frustracji wywoływała wdrażana kolektywizacja. St. wachmistrz Wężyk, dowódca przy 4 baonie KOP „Ostróg”, wyjaśniał motywy dezercji szereg. Michaiła Niemukowa: „Jako powód dezercji zapodał, że gospodarstwo rolne, które w Rosji posiadal, zabrane mu zostało do kolektywu, a ponieważ w przeciagu 6 miesięcy ma być zwolniony $z$ wojska $\mathrm{i}$ w kolektywie nie chce pracować, gdyż jest tam bieda, przeto postanowił popełnić dezercję do Polski" ${ }^{55}$. Perspektywa zwolnienia do rezerwy wydawała się dla szeregowych żołnierzy ZSRR jeszcze gorsza. Życie w cywilu nie było lepsze niż uciążliwości

${ }^{52}$ Meldunek posterunku żandarmerii przy 4 Baonie KOP „Dederkały Duże” dot. dezercji sowieckiego żołnierza do Polski z 7 V 1930 r., ASG, KOP, DDŻ, sygn. 178/138, k. 18.

${ }^{53}$ Meldunek posterunku żandarmerii przy 2 Baonie KOP „Ostróg” dot. przekroczenia granicy do Polski przez sowieckiego żołnierza szer. Iwana Kurenbina z $10 \mathrm{~V}$ 1930 r., ASG, KOP, DDŻ, sygn. 178/138, k. 36.

${ }^{54}$ A. Słonims ki, Moja podróż do Rosji (w 1932 roku), Łomianki 2007, s. 118.

55 Meldunek posterunku żandarmerii przy 2 Baonie KOP „Ostróg” dot. przekroczenia granicy do Polski przez sowieckiego żołnierza szer. Michaiła Niemukowa z 9 VI 1933 r., ASG, KOP, DDŻ, sygn. 178/199, k. 46. 
wojskowej służby. Fatum kołchoźniczej pracy zniechęcało jeszcze bardziej niż wojskowe kamasze.

Sowieccy wojskowi uciekinierzy byli zainteresowani zachodnim kierunkiem. Wybór Polski oznaczał zetknięcie się z zupełnie odmienna rzeczywistością. Służba przy granicy polsko-sowieckiej dla czerwonoarmistów skierowanych tutaj $z$ dalekich obszarów ZSRR była atrakcyjna. Była być może jedyną okazja do poznania zupełnie innej rzeczywistości. Co ciekawe, sowiecka straż graniczna składała się głównie $z$ Rosjan, osób pochodzących $z$ dalekich rejonów Rosji. $Z$ pewnością w nadgranicznej służbie ufano im bardziej niż Ukraińcom czy Białorusinom; przypuszczalnie zakładano, że ci ostatni o wiele chętniej odwiedziliby swoich krewnych po drugiej stronie granicy. Wydawało się, że Rosjanie będą lojalniejsi, co wydawało się logiczne. Równocześnie patrolujący polsko-sowiecką granicę Rosjanie skierowani tu $z$ odległych pułków niejedno już w ZSRR widzieli i niejednego doświadczyli. Po ucieczkach chętnie dzielili się $z$ żołnierzami KOP swoimi refleksjami. Opowieść szer. Siergieja Wawilina mogłaby stanowić dobrą kontrpropagandę dla wszystkich dezerterów $z$ WP, którzy uwierzyli, że ZSRR jest krajem powszechnej radości i szczęścia. Wawilin na posterunku KOP „Dederkały Duże” opowiadał: „Wieśniacy zmuszani do kolektywizacji gospodarstw opieraja się zarządzeniom, zmniejszają przez złą uprawę roli zbór plonów, by tylko wyrządzić szkodę państwu. Ludność wyznania prawosławnego zmuszana jest do zaniechania obrzędów religijnych, a cerkwie zostały w bardzo wielu przypadkach zamknięte"56. Wawilin stanowczo zadeklarował, że pragnie pozostać w Polsce.

Problem masowych dezercji w ZSRR, o których pisał rosyjski historyk, wspomniany Jewgienij Fiedorowicz Krinko, doprowadził do sytuacji, że zbiegli żołnierze łączyli się w przestępcze bandy. Do dzisiaj nierozstrzygnięte pozostaje, czy organizowali się tylko dla akcji rabunkowych, czy też aby łatwiej przedostać się do sąsiedniego kraju. Do takich wydarzeń doszło 16 września 1931 r. Tego dnia nad ranem 15-osobowa uzbrojona grupa stoczyła walkę z sowieckim pogranicznym patrolem. W jej trakcie zginęły trzy osoby, pozostałe wtargnęły na terytorium Polski ${ }^{57}$. Do podobnych starć dochodziło

${ }^{56}$ Meldunek posterunku żandarmerii przy 4 Baonie KOP „Dederkały Duże” dot. przekroczenia polskiej granicy przez sowieckiego żołnierza Siergieja Wawilina z 24 VII 1930 r., ASG, KOP, DDŻ, sygn. 178/110, k. 77.

${ }^{57}$ Meldunek posterunku żandarmerii przy 4 Baonie KOP „Dederkały Duże” dot. przekroczenia polskiej granicy przez osoby cywilne $z$ Rosji sowieckiej do Polski z 17 IX 1931 r., ASG, KOP, DDŻ sygn. 178/138, k. 71. 
w pasie granicznym Polski, Rumunii i Związku Sowieckiego. W rejonie tym operował oddział zbrojny „Kuszniara”. Grupa ta atakowała posterunki należące do straży granicznej ZSRR. Co ciekawe, trzon oddziału składał się $z$ byłych sowieckich pograniczników. W grudniu 1925 r. po krwawej bitwie, w której poległo 20 osób, grupa została zlikwidowana, a jej przywódca zatrzymany ${ }^{58}$.

Do jednej $z$ najsłynniejszych dezercji z ZSRR do Polski doszło w 1934 r. Z cumującego od 1 do 10 września w gdyńskim porcie sowieckiego okrętu liniowego Marat zbiegł Sergiusz Woronkow. Marynarz ukrywał się kilka tygodni, a po ujawnieniu opowiedział polskiej prasie o masowym prześladowaniu ludności w Zwiąku Sowieckim i dramatycznych relacjach żołnierskich w Armii Czerwonej. Dnia 4 listopada 1934 r. Kolegium Sąu Najwyższego w Moskwie wydało na Woronkowa zaoczny wyrok śmierci - został uznany za zdrajcę ojczyzny. Aresztowano jego cała rodzinę, także jego dalszych krewnych, skonfiskowano też cały majątek rodziny zbiegłego żołnierza ${ }^{59}$.

Zaoczny wyrok śmierci Woronkowa sowiecka prasa wydrukowała już 5 listopada 1934 r. „Sprawa Woronkowa” została wykorzystana $\mathrm{w}$ polemice toczonej na łamach przedwojennej prasy związanej $z$ opublikowaniem w „Wiadomościach Literackich” opowiadania Józefa Uniłowskiego Dzień rekruta. Tadeusz Unkiewicz $z$ pisma „Pion” zarzucał „Wiadomościom Literackim”, że nigdy nie napisały nic krytycznego o ZSRR ani o sowieckiej armii. Oburzyło go również milczenie „Wiadomości Literackich” w związku z szeroko dyskutowaną ucieczką Woronkowa, a jednocześnie krzywdzące deformowanie obrazu WP: „Wolą pisać o polskim wojsku, siać w Polsce defetyzm. Nie chodzi im o samo zagadnienie, nie o ideę pacyfistyczną, ale o zdobycie sensacji, poczytności. To się będzie podobać, to takie modne, bezpieczne (u nas takich groźnych dekretów jak w ZSRR nie ma). Tak więc podaniem zafałszowanego obrazu życia wojskowego chce się je ośmieszyć i uczynić zeń zmorę bez sensu, mieląca ludzi w swych mackach. Sieje się świadomie defetyzm, odrazę do wojska. Podkreślam wojska polskiego"60. Wiele wskazuje

${ }^{58} Z$ obcych granic. Bitwa Sowietów z bandytami na pograniczu polsko-rumuńskim, „Czaty” 1925, R. I, nr 41-42, s. 11.

59 Tragedia sowieckiego marynarza, „Sprawy Miesiaca” (dodatek do pisma „Tęcza”) 1934, R. VIII, nr 12; T. Unkiewicz, Kłamliwa enuncjacja, „Pion” 1934, R. II, nr 48 (61), s. 7. Sergiusz Woronkow został skazany na podstawie sowieckiego Kodeksu Karnego z 22 XI 1926 r., art. 139 i 320 kk. oraz dekretu z 28 VI 1934 r.

${ }^{60}$ T. Unkiewicz, op. cit., s. 7. 
na to, że spośród żołnierzy, którzy w latach dwudziestych i trzydziestych uciekli $z$ krajów sąsiednich do Polski, najwięcej pochodziło ze Zwiazku Sowieckiego.

Kolejną dość liczna grupę stanowili żołnierze napływający do Rzeczypospolitej z Rumunii. Rumuńscy żołnierze uciekali do Polski już w latach dwudziestych, Polska wydawała się im wówczas miejscem życzliwym i bezpiecznym. Do głośnego wydarzenia doszło w październiku 1926 r., kiedy polska policja wydała list gończy za zbiegłym Izaakiem Schorem, dezerterem $z$ armii rumuńskiej ${ }^{61}$. Armia rumuńska, choć w polskich kołach wojskowych traktowana jako przyjazne siły zbrojne, nigdy nie zyskała wartościowych recenzji militarno-organizacyjnych. Bardzo źle oceniano jej stan moralny, dyscyplinę, z dezaprobata twierdzono, że skorumpowani oficerowie rumuńscy niewiele się troszczą o byt materialny żołnierzy. Polski ataszat wojskowy w Bukareszcie w czerwcu 1923 r. zauważył, że żołnierze rumuńscy nie żywili żadnego poczucia chluby i przywiazania do munduru narodowego ${ }^{62}$. Nie lepsze opinie panowały w Szt. Gł. WP kilka lat później. W styczniu 1930 r. mjr dypl. Roman Michałowski, attaché wojskowy w Bukareszcie, raportował na temat armii rumuńskiej, że stanowi ona przestarzały system, w którym nie ma ani duszy, ani treści ${ }^{63}$. Masowe dezercje $z$ armii rumuńskiej w latach trzydziestych, notabene nie tylko do Polski, zupełnie więc nie zaskakiwały.

Tylko w lipcu i sierpniu 1933 r. w powiecie śniatyńskim i kosowskim zatrzymano kilkunastu dezerterów $z$ armii rumuńskiej, których odstawiono do dowództwa 11. Dywizji Piechoty w Stanisławowie $^{64}$. Na początku czerwca 1934 r. w województwie stanisławowskim oficjalnie zarejestrowano 23 dezerterów $z$ armii rumuńskiej. Zbiegowie nie cieszyli się dobrą reputacją. Urząd Wojewódzki w Stanisławowie raportował do szefostwa MSW, że większość z nich była karana w Rumunii za różne przestępstwa ${ }^{65}$. W kolejnych latach

${ }^{61}$ Pismo dotyczace poszukiwania Izaaka Schora, dezertera $z$ armii rumuńskiej z 7 X 1926 r., AAN, Komenda Powiatowa Policji Państwowej w Podhajcach, sygn. $50, \mathrm{k} .88$.

${ }_{62}$ M. Leczyk, Polska i sasiedzi. Stosunki wojskowe 1921-1939, Białystok 1997, s. 61.

${ }^{63}$ Ibidem, s. 199.

${ }^{64}$ Pisma Wojewody Stanisławowskiego dotyczace spraw granicznych z 19 VIII i 19 IX 1933 r., AAN, Urząd Wojewódzki w Stanisławowie [dalej: UWS], sygn. 977/4, s. 11, k. 52, 65.

${ }^{65}$ Pismo UWS do MSW w Warszawie, Stanisławów 5 VI 1934 r., AAN, Komenda Główna Policji Państwowej w Warszawie, sygn. 92, k. 176. 
liczba dezerterów z Rumunii nadal była wysoka. Tylko w 1937 r. na obszar II RP przybyło ich co najmniej kilkudziesięciu. Przykładowo: 20 maja 1937 r. posterunek policji w Horodence zatrzymał szer. Gnido Wodnarzika, który porzucił swój 12 Pułk Artylerii w Czerniowcach. W ostatnich dniach sierpnia, a także na początku września 1937 r. placówki graniczne $z$ rejonu Kołomyi zatrzymały kolejnych zbiegów $z$ rumuńskiej armii ${ }^{66}$. Przynajmniej od poczattku lat trzydziestych (niewykluczone, że również w poprzednich latach) Stanisławów - ze względu na bliskość granicy z Rumunią - był miastem, w którym wyznaczono miejsce tzw. stałego pobytu dla dezerterów z Rumunii. Po samowolnym opuszczeniu Stanisławowa, wyjeździe do innych większych miast Polski (najczęściej do Lwowa) rumuńscy dezerterzy byli natychmiast zatrzymywani ${ }^{67}$.

Wydaje się, że wśród dezerterów ze Związku Sowieckiego do Polski przeważali Rosjanie (tak przynajmniej wynika $z$ zachowanych w Polsce dokumentów), z kolei wielu zbiegów z rumuńskiej armii, którzy uciekli do Polski, było Żydami. Żydowscy dezerterzy z armii rumuńskiej przybywali do Polski często w cywilnych ubraniach, mieli ze sobą trochę pieniędzy i prawie zawsze intensywnie poszukiwali pracy, $z$ różnym skutkiem. Sukcesów nie przyniosło życie w nowej ojczyźnie szeregowcowi Aronowi Aronowiczowi. Urodził się on w Batoszanach i od wiosny 1925 r. służył w rumuńskim 37 pp. W lutym 1926 r. zdezerterował i blisko dwa lata pracował w Rumunii. Wiele wskazuje, że pościg rumuńskiej żandarmerii przyczynił się do ucieczki Aronowicza do Polski. Doszło do niej w końcu grudnia 1927 r. Były żołnierz rumuńskiego 37 pp mieszkał kolejno w Kutnie, Lwowie i Krakowie. Wszędzie tam bezskutecznie poszukiwał zatrudnienia. Zapewne zniechęcony niefortunnym pobytem 25 stycznia 1928 r. sam zameldował się na posterunku bielskiej policji ${ }^{68}$. Rumuński dezerter był w cywilnym ubraniu.

W Republice Weimarskiej dezercje były zjawiskiem marginalnym, a to dlatego, że służba wojskowa nie była obowiązkowa. Stutysięczna Reichswehra prowadziła ścisłą selekcję kadrowa, wybierając

${ }^{66}$ Komunikat Informacyjny $\mathrm{nr}$ 6/37 za czas od 1 do 30 VI 1937 r. z 3 VIII 1937 r., ASG, SG 1928-1939, KSG, sygn. 187/138, s. 10; Komunikat Informacyjny nr 9/37 za czas od 1 do 30 IX 1937 r. z 4 XI 1937, ASG, SG 1928-1939, KSG, sygn. 187/138, s. 8-9. W Komunikacie jest mowa o 17 Pułku Artylerii.

67 Aresztowanie dezertera rumuńskiego, „Słowo Polskie” 1931, nr 267, s. 2.

${ }^{68}$ Wykaz imienny dezerterów Powiatowej Komendy PWŚ dot. Arona Aronowicza z 3 II 1928 r. dołaczony do pisma Głównej Komendy PWŚ z 17 II 1928 r., WBH, sygn. I.371.5/A, teczka 265, k. 177. 
najlepszych kandydatów do służby. Preferowano żołnierzy pochodzenia chłopskiego, którzy wydawali się najwłaściwszymi ideowo rekrutami. Unikano osób o przekonaniach lewicowych, a także robotników pochodzacych $z$ okręgów przemysłowych, w których komuniści mieli znaczne wpływy. Szczególnie uważnie tworzono korpus oficerski, który stanowił hermetyczna, wyizolowaną od społeczeństwa i obdarzona przywilejami grupę ${ }^{69}$.

Mimo takich wysiłków nie była to armia idealna. Tylko od czerwca 1931 do grudnia 1932 r. skazano na więzienie 15 żołnierzy tej formacji, oskarżając ich głównie o zdradę tajemnic wojskowych. W tej grupie znalazł się również st. grefjater Gottlieb, skazany nie tylko za wspomniane przestępstwo, lecz także za oszustwo, fałszowanie dokumentów i dezercję. Mimo udowodnienia mu tak poważnych występków otrzymał stosunkowo łagodna karę - dwa lata i sześć miesięcy więzienia ${ }^{70}$.

Sytuacja się zmieniła $z$ dojściem Adolfa Hitlera do władzy, a potem sformowaniem Wehrmachtu. W 1935 r. w Niemczech wprowadzono obowiązkową służbę wojskową. Jednak zauważalny wzrost dezercji w Wehrmachcie przyniosła dopiero II wojna światowa. Walczący żołnierze niemieccy musieli zawsze pamiętać o maksymie Hitlera wyrażonej w Mein Kampf: „Dezerter musi wiedzieć, że jego dezercja pociaga za sobą właśnie to, przed czym chce on uciec. Na froncie można polec, jako dezerter musi się umrzeć"71. Od początku surowa dyscyplina i karność nowo utworzonych niemieckich sił zbrojnych nie sprzyjała dezercjom. W latach 1935-1939 nie wspierał tej tendencji panujący entuzjazm dla nowego kanclerza, służbę w Wehrmachcie pełniono wówczas $z$ dużą ochotą.

Takie nastroje nie oznaczały, że przed wybuchem II wojny światowej w Wehrmachcie dezercji nie było. Najbardziej zdeterminowani do porzucenia sił zbrojnych III Rzeszy w latach 1935-1939 byli poborowi, którzy nie czuli się Niemcami. Jednak przed 1 września 1939 r. tylko nieliczni żołnierze zdecydowali się zbiec do Francji, Belgii i przede wszystkim Szwajcarii. Jedną z ciekawszych dezercji

69 T. Kotłows ki, Historia Republiki Weimarskiej (1919-1933), Poznań 1997, s. 230.

70 D. Grajczak, W. Skóra, Szpiegostwo $w$ niemieckich siłach zbrojnych w 1932 r. w świetle sprawozdania kontrwywiadu Ministerstwa Obrony Rzeszy (Reichswehrministerium), [w:] Studia nad wywiadem $i$ kontrwywiadem Polski w XX wieku, t. II, red. W. Skóra, P. Skubisz, Szczecin 2015, s. 310.

${ }^{71}$ W. Wette, Wehrmacht. Legenda i rzeczywistość, przekł. K. Żarski, Kraków 2008, s. 179. 
była ucieczka mającego słoweńskie korzenie Johana Županca, który - wcielony do Wehrmachtu - tuż przed rozpoczęciem II wojny światowej uciekł do Jugosławii ${ }^{72}$. W czasie II wojny światowej Županec walczył w jugosłowiańskiej partyzantce. Wcześniej był organizatorem tzw. Komitetów Wolnej Karyntii. Swoja pomoc dla zbiegłych niemieckich żołnierzy oferowała też nielegalnie działająca niemiecka organizacja Edelweiss Pirates ${ }^{73}$.

Niemieccy dezerterzy uciekali również do Polski. Major Witold Langenfeld, czyli zastępca szefa Ekspozytury Nr 3. O. II. SGWP w Bydgoszczy, wyliczył, że tylko na terenie Pomorza od 1934 r. doszło do 26-27 dezercji niemieckich żołnierzy ${ }^{74}$. Zazwyczaj byli to żołnierze, którzy nie czuli się Niemcami: Ślązacy z Opolszczyzny, Słowińcy, Kaszubi, Warmiacy i Mazurzy. Jednym z nich był August Arciszewski, który urodził się w Ełku. W pełnym umundurowaniu przekroczył polska granice 16 lutego 1937 r., służył w 23 pp, w Lötzen, dzisiejszym Giżycku. Motywem dezercji Arciszewskiego były niekończące się szykany. Jak wyjaśniał, jako rzymski katolik był prześladowany przez przełożonych i kolegów $z$ pułku ${ }^{75}$. Ostracyzm religijny i narodowościowy był jedna z przyczyn, które przed 1939 r. skłaniały żołnierzy Wehrmachtu do wtedy jeszcze nielicznych dezercji.

$Z$ drugiej strony trudno jednoznacznie stwierdzić, że niemieckie dezercje do Polski zawsze były rzadkie. Tylko od 1 maja do 14 czerwca 1939 r. z III Rzeszy do Rzeczypospolitej zbiegło 11 żołnierzy Wehrmachtu. Podali typowe przyczyny ucieczki: złe traktowanie ze

${ }^{72}$ R. Lasser, Der Partisanenkampf in Kärnten im Zweiten Weltkrieg Fachbereichsarbeit, Verein Erinnern Gailtal, www.erinnern-gailtal.at (dostęp: 28 IX 2014 r.), s. 4.

${ }^{73}$ F. McDonough, Opposition and Resistance in Nazi Germany, Cambridge 2001, s. 17.

${ }^{74}$ R. Majzner, A. Suchcitz, T. Dubicki, Oskarżam majora Żychonia. Sprawa karna $K W$ 21/42 przed Morskim Sadem Wojennym $w$ Londynie, Radomsko 2016, s. 93.

${ }^{75}$ Komunikat Informacyjny $\mathrm{nr}$ 2/37 za czas od 1 do 28 II 1937 r., Warszawa 8 IV 1937 r., ASG, SG 1928-1939 KSG, sygn. 187/138, s. 7. To, jak duże napięcia narodowościowe istniały w niektórych dywizjach Wehrmachtu, potwierdziły wydarzenia z września 1939 r. Jak wspominał mjr Józef Herzog, który uczestniczył w obronie Modlina, co najmniej kilku żołnierzy z niemieckiej 228 DP z Prus Wschodnich, którzy urodzili się na Warmii i Mazurach, po dostaniu się do polskiej niewoli zadeklarowało polska narodowość. Polscy jeńcy $z$ Wehrmachtu prosili o odseparowanie od jeńców niemieckich, jeden $z$ nich zaś wyraził wolę wstapienia do WP. Por. Józef Herzog. Żołnierz niepodległości, Wspomnienia i dokumenty, oprac. i wstęp P. Wywiał, Kraków 2009, s. 57, 296. 
strony podoficerów, obawę przed karą za jakieś wykroczenie, niechęć do służby wojskowej i ustroju politycznego. Co ciekawe, wśród podawanych motywów zbiegostwa znalazło się również niewystarczające wyżywienie $\mathrm{w}$ niemieckiej armii ${ }^{76}$. Po przesłuchaniu przez polski wywiad 11 niemieckich dezerterów staraniem O. II. Szt. Gł. zostało zaopatrzonych $\mathrm{w}$ dokumenty zezwalajace im na pobyt $\mathrm{w}$ Polsce na prawach azylu. Uciekinierom $z$ Wehrmachtu wypłacono zapomogi pieniężne, a zbiegłych w mundurach zaopatrzono w odzież cywilną. Wspomniana grupa dezerterów z Niemiec, jak i wszyscy inni zbiegli w latach trzydziestych $z$ Wehrmachtu, kierowani byli głównie do województw centralnych i wschodnich. W województwach leżących daleko od Niemiec byli zatrudniani przede wszystkim w lasach, tartakach i gospodarstwach rolnych ${ }^{77}$. Nie wszyscy dezerterzy $z$ Niemiec traktowani byli w Polsce jako polityczni uchodźcy, którym w Niemczech grozily represje.

Od września 1938 r. na terenie Polski ukrywał się urodzony w Królewcu Artur Joneleit, w Niemczech ścigany za odmowę wzięcia udziału w ćwiczeniach wojskowych rezerwistów. W Rzeczypospolitej Joneleita intensywnie poszukiwała polska straż graniczna, która na Pomorzu rozesłała za nim list gończy ${ }^{78}$. W dokumentacji archiwalnej brakuje wyjaśnienia, dlaczego Straż Graniczna $z$ Chojnic sprokurowała list gończy. Być może były ku temu powody, ukrywający się w Polsce dezerterzy z państw ościennych mieli niekiedy bogata przeszłość kryminalna, nie każdy zbiegły do Polski żołnierz był ofiarą represji, prześladowanym uchodźcą.

Niemcy, jak i dezerterzy z ZSRR, Czechosłowacji i Litwy, poza tym, że mogli okazać się cennym źródłem wojskowej informacji, przynosili jeszcze jedna korzyść. Całkiem możliwe, że jej znaczenie było cenniejsze niż scharakteryzowanie w wywiadowczym formularzu dyslokacji, uzbrojenia i liczebności swojego pułku. Niezwykle istotna pod tym względem była dezercja mjr. Löwego. Zbiegły pod koniec 1936 r. oficer był szefem wyszkolenia jednego $z$ niemieckich korpusów. O. II. SGWP umieścił niemieckiego oficera w jednym z warszawskich mieszkań na Żoliborzu. W Polsce mjr Löwe otrzymał nowe nazwisko - Lubiński. W 1939 r. został ewakuowany przez

${ }^{76}$ Odpis tajnego pisma dot. dezercji żołnierzy niemieckich do Polski z 21 VI 1939 r., AAN, Ambasada Rzeczypospolitej Polskiej w Berlinie [dalej: ARPB], sygn. 3654, s. 1, k. 43.

77 Ibidem, s. 1-2, k. 43.

${ }^{78}$ List gończy za Arturem Joneleitem z 8 III 1939 r., ASG, SG 1928-1939, Pomorski Inspektorat Okręgowy, sygn. 189/304, k. 238. 
Rumunię, do Francji, a potem do Wielkiej Brytanii. Jak zauważył Aleksander Woźny, Löwe był cennym, ale niedocenionym ekspertem wojskowym: „Na początku 1937 r. przekazał kierownictwu wojska obszerne studium armii niemieckiej i przewidywań dotyczących przyszłej wojny. Oceniał on położenie strategiczne Polski jako bardzo niekorzystne"79.

Na kilka tygodni przed 1 września 1939 r. ucieczki żołnierzy $z$ Wehrmachtu miały kolosalne znaczenie propagandowe. Przypadki ucieczek tzw. prawdziwych Niemców z Wehrmachtu, urodzonych daleko od Polski, $z$ niemieckimi nazwiskami, deklarujacych wyznanie ewangelickie były nagłaśniane, rozpowszechniane, a także celowo wyolbrzymiane. Dezercje niemieckich żołnierzy latem 1939 r. wykorzystywano propagandowo. W lipcu 1939 r. czasopismo straży celnej „Czaty” relacjonowało zatrzymanie w Muszynie-Leluchowie niemieckiego dezertera: „Znamiennym dowodem przereklamowania wartości armii niemieckiej jest szerząca się w jej szeregach dezercja. Oto znów na odcinku placówki Leluchów ujęto dezertera $z$ armii niemieckiej. Jest nim strzelec stacjonowanego w Pradze 23-go pułku artylerii przeciwlotniczej Hartman Herbert Max, urodzony 14 grudnia 1914 r. w Zeulanroda, pow. Grei, rodowity Niemiec i ewangelik"80. Siła bojowa Wehrmachtu $z$ takimi żołnierzami, jak Hartman polskiemu społeczeństwu mogła się wydawać o wiele słabsza.

Informowanie społeczeństwa w Polsce o ucieczkach niemieckich żołnierzy na teren Rzeczypospolitej wywoływało w Niemczech, zwłaszcza w regionach przygranicznych $z$ Polska, ogromne wzburzenie. $Z$ tego powodu 7 lipca 1939 r. w niemieckich gazetach ukazujacych się na Opolszczyźnie rozpętała się prawdziwa histeria. O wydarzeniu tym jeszcze tego samego dnia powiadamiał ambasadę polską w Berlinie Jan Małęczyński, urzędujący konsul RP w Opolu: „W całej dzisiejszej prasie Śląska Opolskiego ukazał się artykuł pod tytułem: Wie die polnischen Kriegshetzer die Schlacht bei Berlin vorbereiten. Artykuł ten stwierdza, że Polska od czasu otrzymania gwarancji angielskich straciła zupełnie rozum i pod kierunkiem wyrafinowanej Anglii prowadzi kłamliwa propagandę antyniemiecka. Jednym $z$ takich kłamstw, sfabrykowanych przez prasę polska sa wiadomości o dezercji żołnierzy niemieckich do Polski z powodu panującego w Niemczech głodu, jak i złego traktowania tych

${ }^{79}$ A. Woźny, Niemieckie przygotowania do wojny z Polska, Warszawa 2000, s. 196.

${ }^{80}$ Dezercja szerzy się w armii niemieckiej, „Czaty” 1939, R. XV, nr 14, s. 28. 
żołnierzy przez ich przełożonych. Ostatnio prasa polska znowu puściła plotkę o dezercji 5 żołnierzy i podoficera niemieckiego do Polski. W ten sposób prasa polska zachęca ludność polską do ataku na Rzeszę regularnie podburzajac ja i starając się w Polsce rozprzestrzenić przekonanie o słabej wartości armii niemieckiej"81.

Rzeczywiście poza złym traktowaniem przez przełożonych, uciskiem religijnym i narodowościowym to zjawisko tzw. powszechnego głodu w Niemczech jako powodu zbiegostwa żołnierzy Wehrmachtu do Rzeczypospolitej było często opisywane przez polskie gazety. Warto zauważyć, że pojawiało się nie tylko latem 1939 r., lecz także choćby w sierpniu 1938 i kwietniu 1939 r. ${ }^{82}$ Niekiedy polskie gazety ograniczały się do krótkich komunikatów, nie analizując przyczyn dezercji, a podając jedynie personalia i jednostkę wojskową niemieckich zbiegów ${ }^{83}$.

Ucieczki z Wehrmachtu, które symbolizowały złą jakość niemieckiej armii, nie były jednak rozpowszechniane tylko przez polskie gazety. Władysław Polesiński wykorzystał je również w propagandowej książce Żołnierz polski, a żołnierz niemiecki. Analiza wartości wojennych, która ukazała się w 1939 r. Książka ta miała przekonać odbiorców, że umiejętności bojowe i etos żołnierza polskiego bija na głowę żołnierza niemieckiego. Jednym $z$ argumentów słabości armii były dezercje, których kilkanaście przypadków Polesiński wyliczał w swoje publikacji. W jego opinii źródło dezercji niemieckich żołnierzy tkwiło w złym traktowaniu przez oficerów, szykanach i głodzie. Autor podkreślał, że dezerterzy to żołnierze narodowości niemieckiej, pisząc, że: „Podobnych zdarzeń polska armia nie zna" ${ }^{4}$. Według Polesińskiego nie mniejsze przyczyny zbiegostwa $z$ Wehrmachtu leżały $\mathrm{w}$ prześladowaniach żołnierzy wyznania rzymskokatolickiego. Antycypował, że: „W czasie wojny, gdy możność ucieczki będzie znacznie łatwiejsza, ilość tych zbiegostw niepomiernie wzrośnie" 85 .

${ }^{81}$ Pismo Konsulatu Generalnego RP w Opolu dot. dezercji żołnierzy niemieckich do Polski z 7 VII 1939 r., AAN, ARPB, sygn. 3654, s. 1, k. 44.

82 (b e n), Głód $w$ armii niemieckiej powodem dezercji, „Siedem Groszy” 1938, R. VII, nr 238, s. 3; Dezerter z armii niemieckiej zbiegł do Polski, „Głos Mazowiecki” 1939, R. VII, nr 92-93, s. 2.

${ }^{83}$ Dezerter z armii niemieckiej, „Goniec Nadwiślański” („Głos Pomorski”) 1938, nr 246, s. 7.

${ }^{84}$ W. Poles ińs ki, Żołnierz polski, a żołnierz niemiecki. Analiza wartości wojennych, Warszawa 1939, s. 24.

${ }^{85}$ Ibidem, s. 29. 
Wydaje się, że większy zasięg niż niemieckie dezercje do Polski miały ucieczki żołnierzy $z$ Czechosłowacji. Jednak podobnie jak w przypadku sowieckim czy niemieckim trudno określić jej dokładną liczbę. Nielegalne zbiegostwo $z$ Czechosłowacji polska policja i straż graniczna notowały w latach dwudziestych i trzydziestych. Wśród dezerterów byli żołnierze wielu narodowości. W 1924 r. polskie służby zatrzymały m.in. Czecha Jana Pauera, a także Abrahama Weintrauba, żydowskiego żołnierza pochodzącego $z$ Brna $^{86}$. W drugiej połowie lat trzydziestych wzmogły się ucieczki do Polski żołnierzy słowackich. Fakty te potwierdzały jedynie coraz większy separatyzm Słowacji. W grudniu 1937 r. zbiegł do Polski szer. Stefan Palej, który porzucił swój 16 pp stacjonujący w Preszowie. Przesłuchujacym go polskim funkcjonariuszom SG $z$ Leluchowa k. Muszyny oświadczył, że jest to już jego druga ucieczka ${ }^{87}$.

Postępujacą dezintegrację Czechosłowacji, której jednym z przejawów był wzrost niechęci do wojska mniejszości narodowych, $z$ uwaga obserwowano w Polsce. O wzbierajacej fali wojskowego zbiegostwa chętnie wspominała codzienna polska prasa. Tylko 17 i 20 września 1938 r. krakowskie „Ostatnie Wiadomości Poranne” (wcześniej wydawane pod tytułem „Ostatnie Wiadomości Krakowskie”) informowały, że rezerwiści niemieccy mieszkajacy w Sudetach masowo nie stawiali się na wezwanie do jednostek wojskowych. Gazeta wydawana w Krakowie donosiła również, że wśród 37 tys. niemieckich uchodźców z Czechosłowacji większość stanowili poborowi ${ }^{88}$. W czasie tzw. II kryzysu sudeckiego do armii nie stawiło się prawdopodobnie $50 \%$ poborowych narodowości niemieckiej. Bardzo poważne niestawiennictwo odnotowano również wśród poborowych narodowości węgierskiej i polskiej. Przykładem może być czechosłowacki 8 pp, do którego nie zgłosiło się 1286 rezerwistów narodowości niemieckiej i 400 narodowości polskiej ${ }^{89}$.

${ }^{86}$ Pismo Ekspozytury nr IV O. II. Szt. Gł. do SRI, DOK nr V w Krakowie z 27 I 1925 r., WBH, SRI, DOK V, sygn. I.371.5/A, teczka 265, k. 180; Wykaz dezerterów armii obcych z 17 I 1925 r., WBH, SRI, DOK V, sygn. I.371.5/A, teczka 265, k. 181.

87 Komunikat Informacyjny nr 12/37 za czas od 1 do 31 XII 1937 roku z 16 II 1938 r., ASG, SG 1928-1939 KSG, sygn. 187/138, s. 9.

${ }^{88}$ Rezerwiści - Niemcy sudeccy odmawiaja posłuszeństwa władzom czeskim, „Ostatnie Wiadomości Poranne” 1938, R. I (VII), nr 107 (260), s. 5; 37 tysięcy Niemców uciekło z Czechosłowacji, znajdując schronienie w Rzeszy, „Ostatnie Wiadomości Poranne" 1938, R. I (VII), nr 110 (263), s. 1.

89 J.P. Wiśniewski, Armia czechosłowacka $w$ latach 1932-1938, Toruń 2002, s. 205. 
Na skutek dezercji pułki czechosłowackie miały zostać zdekompletowane. W czeskich pułkach we wrześniu 1938 r. występowały poważne braki żywnościowe. Jednak kwestie bytowe nie były główna przyczyna zbiegostwa. $Z$ armii uciekali żołnierze niemieccy, którzy nie chcieli stanąć do walki przeciwko swoim braciom. Dezerterzy dopuszczali się także działań sabotażowych. Pogarszające się nastroje społeczno-polityczne $z$ uwaga śledziła również polska prasa. Być może nawet wyolbrzymiając ich skalę, a także podając różne niesprawdzone informacje ${ }^{90}$.

Nie wszyscy dezerterzy z Czechosłowacji traktowali Polskę jako miejsce docelowe. Dla zbiegłych $z$ komunistycznego wschodu nasz kraj był przepustką na Zachód. Dla zafascynowanej komunizmem czeskiej młodzieży Rzeczypospolita stanowiła paradoksalnie najdogodniejsze miejsce do bliskich bram „czerwonego raju”. Dla czeskich dezerterów Jana Matoški i Františka Wagnera Polska miała być tylko krajem tranzytowym. Zbiedzy planowali, że przez Polskę najszybciej trafią do ZSRR. Czescy żołnierze uciekli z pułków wojskowych w Ołomuńcu (Matoška służył jako zawodowy sierżant w 302 pułku artylerii ciężkiej, a Wagner jako szereg. w 27 pp.). Polscy śledczy od razu zwrócili uwagę, że Czesi przed służbą w wojsku pracowali jako fachowcy. Matoška był maszynistą kolejowym, a Wagner dekarzem. Dostali się do Polski w cywilnych ubraniach, dysponując znacznymi kwotami. Dzięki temu udało im się przekupić czeskiego strażnika granicznego i polskiego funkcjonariusza policji z nadgranicznego posterunku w Kaczycach. Korupcja sprawiła, że spokojnie przeszli przez przejście graniczne w Piotrowicach. Do ZSRR nie podą̇ali sami. Kiedy 8 sierpnia 1923 r. bez kłopotu przekroczyli granicę Polski i Czechosłowacji, towarzyszyło im dwóch czeskich cywilów. Czwórka podażała do Charkowa, do którego prowadził ich Majda, jeden z cywilów. Majda trafił do Charkowa jako jeniec austriacki, przebywał tam pięć lat. Cywil zapewniał zbiegłych żołnierzy, że w sowieckim Charkowie będą na nich czekać intratne posady. Mit Charkowa silnie wpływał na wyobraźnię sfrustrowanych dotychczasową rzeczywistością dezerterów. Narzekali na niski żołd w czeskiej armii i bardzo surową dyscyplinę ${ }^{91}$. Schludny wygląd czeskich dezerterów

90 Pułki czeskie zdekompletowane wskutek masowej dezercji, „Tempo Dnia” 1938, R. VI, nr 268 (1963), s. 2.

${ }^{91}$ Raport gen. Andrzeja Galicy dowódcy I Dywizji Górskiej dotyczący J. Matoški i F. Wagnera, dezerterów z wojska czeskiego z 13 VIII 1923 r., WBH, SRI, DOK V, sygn. I.371.5/A, teczka 265, k. 199. 
i niezłe jak na ówczesne czasy wykształcenie wzbudziły po stronie polskiej podejrzenia. Na początku założono więc, że Czesi przybyli do Polski w roli szpiegów. Obraz Matoški i Wagnera w żaden sposób nie pasował do stereotypu brudnego, sfrustrowanego i wystraszonego dezertera. Po żmudnej analizie uznano jednak, że Czesi nie są wojskowymi wywiadowcami. Gen. Andrzej Galica w swoim raporcie ocenił ich raczej jako ogłupionych ideologia komunistyczna idealistów, którzy za namową cywila Madeja wyruszyli szukać eldorado w Zwiazku Sowieckim. Galica pisał: „Obaj dezerterzy posiadaja staranne ubrania cywilne, mówią po czesku i niemiecku, do języka rosyjskiego się nie przyznają. Matoszka i Wagner najprawdopodobniej padli ofiara agitacji komunistycznej i ulegli namowom robotnika Majdy, który ich chciał przeprowadzić do Rosji. Wymienionych trudno podejrzewać o szpiegostwo, gdyż nie znaja języka polskiego, nie posiadaja żadnych dokumentów osób oraz wybrali się równocześnie we czwórkę za granicę Czechosłowacji"92. Gen. Galica upewnił się też, że Matoška i Wagner nie pozoruja dezercji. Dowodem miała być wyczerpująca relacja, jaką złożył ten pierwszy na temat sił wojskowego garnizonu w Ołomuńcu. Matoška scharakteryzował wszystkie ołomunieckie pułki. Czeski dezerter oszacował również liczbę wszystkich żołnierzy w ołomunieckim okręgu wojskowym na ok. 15 tys. żołnierzy. Najcenniejsze okazało się jednak co innego. Uzyskano nową informację, że na terenie Ołomuńca kwateruja ukraińskie oddziały robotnicze, co w raporcie podkreślono.

Dwójkę cywilów po zapłaceniu grzywny zwolniono i odstawiono na granicę $z$ Czechosłowacją. Mimo obowiązujących od marca i kwietnia 1923 r. procedur zwiazanych $z$ dezerterami zbiegłymi $z$ obcych armii, policja w Bielsku wykazała całkowita bezczynność ${ }^{93}$ - nie wdrażając żadnych procedur, przekazała czeskich dezerterów miejscowemu sądowi.

Od połowy sierpnia 1923 r. Matoška i Wagner przebywali w areszcie sądowym w Bielsku. Tutejszy sąd uznał, że nie są szpiegami. Zadecydowano także, że zbiegom nie przysługuje azyl polityczny. Uciekinierzy $z$ ołomunieckich pułków mieli zostać odstawieni na przejście graniczne $z$ Czechosłowacja. Dodatkowo postanowiono, że Matoška odpowie karnie za skorumpowanie funkcjonariusza polskiej policji. Negatywne perspektywy skłoniły czeskich dezerterów do ucieczki. Dla Wagnera pomyślnej, a dla Matoški nieudanej,

\footnotetext{
92 Ibidem.
}

93 Ibidem. 
ponieważ zraniony trafił do szpitala w Cieszynie. Za Wagnerem bielski sąd rozesłał list gończy ${ }^{94}$. Nagły zamiar wydostania się $z$ aresztu osadzonych zbiegów z Ołomuńca miał też inna przyczynę - polska prokuratura ustaliła, że zbiegli żołnierze dopuścili się licznych kradzieży w swoich pułkach.

Polskę jako drogę ucieczki wybierało w Czechosłowacji wielu dezerterów recydywistów. Być może liczyli, że w słowiańskim kraju będzie im łatwiej się schronić niż w obcojęzycznych Austrii i Niemczech. Uważali też, że $z$ Polski najłatwiej było przedostać się do ZSRR, w którym oczekiwano zupełnej bezkarności.

Jesienia 1921 r. w Stryju zatrzymano Ladislava Kolena. Czeski dezerter urodził się w Pilźnie. Już wcześniej karano go za fałszowanie dokumentów. Dnia 30 września 1921 r. sąd w Bratysławie skazał Kolena za dezercję na dwa lata więzienia. Jeszcze tego dnia zbiegł eskorcie, która konwojowała go do więzienia w Komarnie. Szybko przedostał się do Polski, gdzie posługiwał się fałszywym dokumentem tożsamości. W końcu października 1921 r. został zatrzymany jako Leon Korsakow, a polscy śledczy uważali go początkowo za szpiega $^{95}$. W dniu 1 listopada 1921 r. wyrokiem Sądu Okręgowego w Stryju Kolena został ukarany pięciodniowym aresztem za nielegalne przekroczenie polskiej granicy. Następnie przekazano go do dyspozycji Prezydium Dyrekcji Policji w celu wydalenia $z$ Polski.

Nie wszyscy dezerterzy $z$ Czechosłowacji byli zatrzymywani, aresztowani i wydalani z Rzeczypospolitej. Zdarzało się, że udzielano im azylu i gościnności, a oni dobrze odnajdowali się w polskich realiach. Tak było m.in. $z$ Janem Dolakiem, który między listopadem 1919 a czerwcem 1920 r. służył w 7 pułku dragonów w Kromieryżu. W dniu 10 czerwca 1920 r. zniknął ze swojego pułku. Po tygodniu przybył do Wisły. Po pozytywnej weryfikacji otrzymał zgodę na pobyt w Polsce. Zaaklimatyzował się wyjątkowo dobrze, pracował jako robotnik leśny. W ciagu ponad trzyletniego pobytu w nowej ojczyźnie tylko raz został ukarany za przekroczenie tzw. cudzej własności. Mimo tego incydentu komenda powiatowa policji w Cieszynie wystawiła mu w tzw. wykazie dezerterów pozytywne świadectwo. Aspirant Pagan w sierpniu 1923 r. opiniował: „Poza

${ }^{94}$ Raport dowództwa I Dywizji Górskiej dot. ucieczki $z$ aresztów sądowych Jana Matoszki i Franciszka Wagnera z 30 X 1923 r., WBH, SRI, DOK V, sygn. I.371.5/A, teczka 265, k. 196. W polskich dokumentach nazwisko Matoška jest często zapisywane jako Matoszka.

${ }_{95}$ Pismo Okręgowej Komendy Policji Państwowej w Krakowie z 8 XI 1921 r., WBH, SRI, DOK V, sygn. I.371.5/A, teczka 175, k. 205. 
tym pracuje i żyje uczciwie, nie występuje praktycznie ani nie jest podejrzany o jakiekolwiek szpiegostwa"96.

Dezerterów $z$ obcych państw, którym zezwolono na zamieszkanie $\mathrm{w}$ Polsce, nie witano $z$ entuzjazmem. Jeszcze raz trzeba przypomnieć, że tylko nieliczni $z$ nich mieli jakieś ważne i cenne informacje dla wywiadu wojskowego. Ucieczki tylko niektórych wykorzystano w działaniach propagandowych. Dla tak niezamożnego kraju, jak Polska pobyt dużej liczby tych specyficznych emigrantów pomnażał różnego rodzaju problemy i generował koszty. Dezerterzy stanowili wyzwanie społeczne i ekonomiczne. Podjęcie pracy przez taka osobę i jej aprobata w lokalnym środowisku nie zawsze należały do łatwych. Byli dezerterzy stanowili stałe, dodatkowe obciążenie dla pracy policji. Jej funkcjonariusze przez kolejne lata dyskretnie inwigilowali takich obywateli, co potwierdzała opisana historia zamieszkałego w Wiśle Dolaka.

Dlatego też Polska podejmowała nieoficjalnie negocjacje $z$ sasiednimi krajami w sprawie ograniczenia przepływu dezerterów. Na tajnych spotkaniach poruszano kwestię wzajemnej wymiany zbiegłych żołnierzy. Bardzo interesujące pod tym względem obrady toczyły się w grudniu 1929 r. między nieutrzymującymi z sobą stosunków dyplomatycznych Polską i Litwą. Na wspólnej konferencji koło Wiżajn doszło do zawarcia układu między tymi krajami w sprawie wymiany dezerterów. Podczas kilkugodzinnych dyskusji opracowano wzór instrukcji, którą planowano przesłać obu rządom do ewentualnego zatwierdzenia ${ }^{97}$. Instrukcja nigdy nie została wprowadzona w życie.

W kwestii dezerterów nie powstały również specjalne umowy z Niemcami, Łotwa, Rumunią i Czechosłowacją. Z tym ostatnim krajem podpisanie umowy w tzw. przedmiocie pomocy prawnej w sprawach administracyjno-wojskowych było najbardziej realne w $1928 \mathrm{r}$. Na odstapieniu od sfinalizowania umowy zaważyło krytyczne stanowisko O. II. SGWP, uznano bowiem, że współdziałanie z Czechosłowacją wobec dezerterów bądź uciekających przed poborem do sąsiedniego kraju mogło przynieść więcej strat niż zysku. Jak pisał mjr dypl. Ludwik Lepiarz: „Równocześnie zaznaczam, że o ile pomoc ta rozciagałaby się na wypadki ucieczki przed poborem i dezercji

96 Wykaz dezerterów armii obcych Powiatowej Komendy PWŚ w Cieszynie z 13 VIII 1923 r., WBH, SRI, DOK V, sygn. I.371.5/A, teczka 265, s. 1, k. 193.

97 Układ między Polska a Litwa w sprawie wymiany dezerterów, „Czaty” 1929, R. V, nr 33, s. 12 . 
z szeregów, należałoby się zastanowić, czy ujawnienie tych faktów obcemu państwu w drodze "pomocy", zwłaszcza o ile zachodziłyby dość licznie, jest wskazane, biorąc pod uwagę chociażby względy polityczne (dezercje Ukraińców, Żydów)"98. Należy przypomnieć, że mjr dypl. Lepiarz od 1928 r. aż do momentu aresztowania w 1936 r. był radzieckim szpiegiem, za co został skazany na karę śmierci.

W latach dwudziestych oraz trzydziestych XX w. na polsko-sowieckiej granicy funkcjonowały tzw. mieszane konferencje (zwane także komisjami) graniczne. Komisje składały się $z$ polskich i sowieckich funkcjonariuszy. Celem tych zespołów było wspólne przesłuchiwanie żołnierzy, którzy nielegalnie przekroczyli granicę. Zebrana komisja sprawdzała, czy przejście przez granicę nastąpiło przypadkowo czy świadomie. Mieszane konferencje na wyznaczonym odcinku pasa granicznego ustalały, czy dezerterzy deklaruja chęć powrotu do ojczyzny, czy pragna zostać w sąsiednim kraju. Decyzje żołnierzy służących w WP lub Armii Czerwonej były różne.

Jedno $z$ ciekawszych posiedzeń konferencji granicznej odbyło się 30 października 1929 r. Przed komisją mieszaną na punkcie granicznym w Ostrogu stanął sowiecki żołnierz Nikołaj Szewc. Dezerter, który pochodził $z$ guberni saratowskiej, zdecydowanie potwierdził, że wybiera pobyt w Polsce ${ }^{99}$. Sowiecki żołnierz przybył do Rzeczypospolitej na koniu, w pełnym wyposażeniu i uzbrojeniu. Jako przyczynę dezercji podawał dalszą niechęć do służby w wojsku sowieckim.

Komisje graniczne nie miały również wpływu na zwrot wyposażenia wojskowego i broni. Sytuacja zmieniła się w 1933 r. - 3 czerwca Polska i ZSRR podpisały w Moskwie Konwencję o trybie badania i rozstrzygania incydentów i zatargów granicznych. W uzupełnieniu art. 4 protokołu końcowego Konwencji obie strony postanowiły, że wszelkiego rodzaju mienie wojenne, które było nielegalnie lub przypadkowo wniesione na terytorium jednej ze stron, będzie natychmiast zwracane drugiej umawiającej się stronie ${ }^{100}$. Przynaj-

98 Pismo dot. pomocy prawnej w sprawach wojskowych Polski i Czechosłowacji, Warszawa 19 VII 1935 r., WBH, Departament Sprawiedliwości, sygn. I 300.58, teczka 277, k. 36.

${ }^{99}$ Meldunek posterunku żandarmerii przy 11 Baonie KOP „Ostróg” dot. przekroczenia polskiej granicy przez szer. M. Szewca z 4 XI 1929 r., ASG, KOP, DDŻ, sygn. 178/138, k. 23.

100 Protokół końcowy Konwencji o trybie badania i rozstrzygania incydentów i zatargów granicznych zawarty pomiędzy Rzeczpospolitą Polską a ZSRR, Moskwa 3 VI 1933, AAN, Prezydium Rady Ministrów, sygn. RKT 22, teczka 86, s. 1, k. 13. 
mniej więc w teorii od czerwca 1933 r. zwrot broni, ładownic lub wojskowego konia był możliwy.

Wielu obywateli Rzeczypospolitej, a także urzędników różnego szczebla administracji państwowej szukało dobrego pretekstu do deportacji uchodźców (szczególnie $z$ armii rumuńskiej). Takie przedsięwzięcie nie należało jednak do łatwych. W myśl obowiązującego prawa dezerter nie mógł być wydalony do kraju, z którego uciekł. Nie mogło się tak stać nawet w wypadku, kiedy dezerter został w Polsce skazany za przestępstwo lub, jak pisano, „stał się ciężarem dobroczynności publicznej"101.

Okólnik Nr 5 MSW z 4 maja 1932 r. wyraźnie wskazywał, że dezertera nie można ponownie skierować do kraju, z którego zbiegł. Ministerstwo Sprawiedliwości przypominało, że taka decyzja oznaczałaby złamanie nie tylko polskiego rozporządzenia, lecz także prawa międzynarodowego. W przypadku jednak, gdyby dezertera ścigały za przestępstwa pospolite władze kraju, z którego zbiegł, mógł on zostać im przekazany ${ }^{102}$.

Takie przypadki były jednak zawsze skomplikowane, co potwierdzała sprawa rumuńskiego oficera Aleksandra Mareanu. Według śledztwa rumuńskiej policji w Czerniowcach Mareanu $z$ wojskowego pułku zdefraudował 4 miliony lei, po czym latem 1928 r. zbiegł do Polski. Na wniosek rumuńskiej policji został aresztowany we Lwowie i odpowiadał przed sądem wojskowym i - jak w październiku 1928 r. twierdził lwowski „Dziennik Ludowy” - w myśl ustaw międzynarodowych nie mógł być wydany władzom rumuńskim ${ }^{103}$. Wybrano więc zupełnie inne rozwiązanie. Bezpośrednio nie przekazano go rumuńskiej policji, ale 8 stycznia 1929 r. odstawiono go na granicę rumuńską ${ }^{104}$.

Przed 1939 rokiem do Polski uciekali nie tylko dezerterzy ze Związku Sowieckiego, Niemiec, Czechosłowacji, Litwy, Węgier i Rumunii. Schronienia szukali tu także zbiegli agenci policji czy wywiadu

101 Odpis pisma Ministerstwa Sprawiedliwości [dalej: MS] do MSZ w sprawie postępowania $z$ dezerterami $z$ obcych państw, Warszawa 21 VII 1934, AAN, MSW, sygn. 1888, k. 179.

102 Poufne pismo MS do MSZ dot. postępowania $z$ dezerterami $z$ obcych państw, Warszawa 21 VII 1934, AAN, MSW, sygn. 1888, k. 183.

103 Oficer rumuński przed sadem we Lwowie, „Dziennik Ludowy” 1928, R. XI, nr 240, s. 5.

${ }^{104}$ Rumuński oficer-dezerter $i$ defraudant Aleksander Mareanu, aresztowany we Lwowie, odstawiony został wczoraj do granicy rumuńskiej, "Gazeta Lwowska” 1929, R. 119, nr 7, s. 4. 
wojskowego $z$ innych państw. Przykładowo w listopadzie 1925 r. polski O. II. Szt. Gł. poszukiwał Budulovica i Severskyego. Oficerowie ci w czasie wojny 1914-1918 mieli być szefami informacji rumuńskiej floty, a także funkcjonariuszami policji rosyjskiej. Według oceny polskiego wywiadu osoby te w latach 1919-1920, kierujac się przez Odessę, Konstancę i Jassy, dotarły do Polski. Polska nie była $z$ pewnościa $w$ kręgu zainteresowania tych agentów. Jak pisał płk Michał Bajer, ówczesny szef O. II. Szt. Gł. WP, osoby te schroniły się w Polsce ${ }^{105}$. Poszukiwania rumuńskich oficerów bez większego sukcesu prowadzono też na terenie Wolnego Miasta Gdańska.

W II RP schronienie znajdowali żołnierze $z$ armii sowieckiej, litewskiej, czechosłowackiej, niemieckiej, rumuńskiej, węgierskiej, a nawet francuskiej. Nasz kraj przed 1939 r. stanowił tranzyt lub docelowe miejsce dla uciekinierów $z$ armii obcych, $w$ tym głównie państw sąsiednich. Nie jest możliwe dokładnie oszacowanie liczby dezerterów $z$ innych krajów, którzy przybyli i pozostali w Polsce. Prawdopodobnie jednak w latach 1920-1939 (nie wliczajac w to wojny polsko-rosyjskiej) znalazło się od 600 do 800 dezerterów z ZSRR, od 500 do 700 dezerterów rumuńskich, od 300 do 400 dezerterów $z$ armii czechosłowackiej (w większości zbiegłych w 1938 r.). Być może było też od 150 do 200 dezerterów z Wehrmachtu (zbiegłych przede wszystkim w latach 1937-1939), a także od 100 do 150 uciekinierów $z$ armii litewskiej (nie wliczając $\mathrm{w}$ to roku 1920). Zupełnie brakuje informacji o przebywajacych w Polsce dezerterach $z$ armii łotewskiej. Raz jeszcze należy podkreślić, że liczby te sa przybliżonym szacunkiem. $Z$ pewnościa w ich zweryfikowaniu pomogłyby kwerendy w archiwach czeskich, niemieckich, litewskich, rosyjskich czy też rumuńskich.

Jeszcze trudniej opisać późniejsze losy dezerterów sprzed 1939 r., których w Polsce zastała II wojna światowa. Czy okupujący ziemie polskie Niemcy i Sowieci systematycznie poszukiwali byłych zbiegów? Jaki los czekał w latach 1939-1945 zatrzymanych dezerterów z Wehrmachtu i Armii Czerwonej? To także zupełnie niezbadany i nieznany w Polsce temat.

105 Rozkaz płk [Michała] Bajera, szefa O. II. Sztab. Gen. dotycz. zbierania informacji o Budilovicu i Severskym z 14 X 1925, WBH, SRI, DOK VIII, sygn. I.371.8/A, teczka 364, k. 157. 


\section{Bibliografia}

\section{Ź́ródea ARChiwalne}

Archiwum Akt Nowych

Ambasada Rzeczypospolitej Polskiej w Berlinie, sygn. 3654.

Komenda Główna Policji Państwowej w Warszawie, sygn. 92.

Komenda Powiatowa Policji Państwowej w Podhajcach, sygn. 50.

Ministerstwo Spraw Wewnętrznych, sygn. 1888.

Prezydium Rady Ministrów, sygn. RKT 22, teczka 86.

Urząd Wojewódzki w Stanisławowie, sygn. 977/4.

Urząd Wojewódzki w Wołyniu, sygn. 979/53.

Archiwum Narodowe w Krakowie

Komenda Wojewódzka Policji Państwowej w Krakowie, sygn. 96.

Archiwum Państwowe w Bydgoszczy

Komenda Wojewódzka Policji Państwowej w Toruniu, sygn. 157.

Archiwum Straży Granicznej w Szczecinie

Korpus Ochrony Pogranicza, Dowództwo Dywizjonu Żandarmerii, sygn. 178/ 110 , sygn. $178 / 138$, sygn. $178 / 199$.

Korpus Ochrony Pogranicza, Dowództwo Korpusu Ochrony Pogranicza, sygn. $177 / 277$.

Straż Graniczna 1928-1939. Komenda Straży Granicznej, sygn. 187/138.

Straż Graniczna 1928-1939. Pomorski Inspektorat Okręgowy, sygn. 189/304.

Wojskowe Biuro Badań Historycznych (byłe Centralne Archiwum Wojskowe)

Akta Spraw Sąów i Prokuratur Wojskowych sygn. I.351.33, teczka 213.

Departament Sprawiedliwości M.S. Wojsk., sygn. I 300. 58, teczka 277.

Naczelne Dowództwo Wojska Polskiego, sygn. I.301.8, teczka 338; sygn. I.301.8, teczka 489.

Samodzielny Referat Informacyjny Dowództwa Okręgu Korpusu nr V sygn. I.371.5./A., teczka 175; sygn. 371.5/A., teczka 233; sygn. 371.5/A., teczka 263; sygn. I.371.5/A, teczka 265.

\section{ŹRÓDEA DRUKOWANE}

Genet J., Dziennik złodzieja, przekł. P. Kamiński, Kraków 2004.

Józef Herzog. Żołnierz niepodległości, Wspomnienia i dokumenty, oprac. i wstęp

P. Wywiał, Kraków 2009.

Słonimski A., Moja podróż do Rosji (w 1932 roku), Łomianki 2007. 


\section{Prasa}

„Czaty” 1925, 1929, 1939.

„Dziennik Ludowy” 1928.

„Gazeta Lwowska” 1929.

„Głos Mazowiecki” 1939.

„Goniec Nadwiślański” („Głos Pomorski”) 1938.

„Ostatnie Wiadomości Poranne” 1938.

„Pion” 1934.

„Siedem Groszy” 1938.

„Słowo Polskie” 1931.

„Sprawy Miesiaca” (dodatek do pisma „Tęcza”) 1934.

„Tempo Dnia” 1938.

„Wojskowy Przegląd Prawniczy” 1936.

\section{OpRacowania}

Banach K., Służba informacyjna w pułku piechoty w czasie wojny, Warszawa 1936.

Banach K., Zasady i metoda pracy Oddziału II Sztabu, Warszawa 1938.

Czernielewski K., Jarno W., Garnizon Łódzki Wojska Polskiego 1918-1939, Toruń 2008.

Ćwięk H., Działalność wywiadu sowieckiego na polskim pograniczu w latach trzydziestych, Warszawa 1995.

Dubicki T., Suchcitz A., Oficerowie wywiadu WP i PSZ w latach 1939-1945, t. II (Słownik biograficzny), Warszawa 2011.

Dattas L., Cnotliwy żywot Jeana Geneta, przekł. K. Kot, Warszawa 2009.

Grajczak D., Skóra W., Szpiegostwo $w$ niemieckich siłach zbrojnych w 1932 r. $w$ świetle sprawozdania kontrwywiadu Ministerstwa Obrony Rzeszy (Reichswehrministerium), [w:] Studia nad wywiadem i kontrwywiadem Polski $w$ XX wieku, t. II, red. W. Skóra, P. Skubisz, Szczecin 2015, s. 289-330.

Grzybowski J., Białorusini $w$ polskich formacjach wojskowych $w$ latach 19181945, Warszawa 2006.

Jaroszuk E., Żandarmeria Wojskowa w latach 1921-1939, Kraków 2009.

Kotłowski T., Historia Republiki Weimarskiej (1919-1933), Poznań 1997.

Krinko J.F., Hużje Wraga. Djezjerstwo w ZSRR nakanunje i w gody Wjelikoj Otwjeczjestwjennoj wojny w: Istorija i Istoriki $w$ kontjekstje Wrjemjeni, „Naucznyj Żurnal" [Moskwa] 2011, z. 8, s. 90-105.

Leczyk M., Polska i sąsiedzi. Stosunki wojskowe 1921-1939, Białystok 1997.

Majzner R., Suchcitz A., Dubicki T., Oskarżam majora Żychonia. Sprawa karna KW 21/42 przed Morskim Sadem Wojennym w Londynie, Radomsko 2016.

McDonough F., Opposition and Resistance in Nazi Germany, Cambridge 2001.

Milewski L., Dezercja cudzoziemca, „Wojskowy Przegląd Prawniczy” 1936, R. IX, nr 2, s. 39-44. 
Misiuk A., Służby specjalne II Rzeczypospolitej, Warszawa 1998.

Pasek W., „Żmudzin” Bolesław Kontrym 1898-1953, Warszawa 2006.

Pepłoński A., Kontrwywiad Drugiej Rzeczypospolitej, Warszawa 2002.

Polesiński W., Żołnierz polski, a żołnierz niemiecki. Analiza wartości wojennych, Warszawa 1939.

Smoliński A., Dezercje z 1 Armii Konnej podczas jej walk na polskim teatrze działan wojennych w 1920 r., Białystok 2008.

Smoliński A., Dezercje z Robotniczo-Chłopskiej Armii Czerwonej w latach 19181922. Wojna z Polska i wojna domowa w Rosji, „Przegląd Wschodni” 2007, t. X, z. 3 (39), s. 675-722.

Studia nad wywiadem i kontrwywiadem Polski $w$ XX wieku, t. II, red. W. Skóra, P. Skubisz, Szczecin 2015.

Wette W., Wehrmacht. Legenda i rzeczywistość, przekł. K. Żarski, Kraków 2008.

Wiśniewski J.P., Armia czechosłowacka w latach 1932-1938, Toruń 2002.

Wołos M., O Piłsudskim, Dmowskim i zamachu majowym. Dyplomacja sowiecka wobec Polski w okresie kryzysu politycznego 1925-1926, Kraków 2013.

Woźny A., Niemieckie przygotowania do wojny z Polska, Warszawa 2000.

Zamoyski A., Warszawa 1920. Nieudany podbój Europy. Klęska Lenina, Kraków 2009.

\section{Netografia}

Lasser R., Der Partisanenkampf in Kärnten im Zweiten Weltkrieg Fachbereichsarbeit, Verein Erinnern Gailtal, www.erinnern-gailtal.at (dostęp: 28 IX 2014 r.)

REMIGIUSZ KASPRZYCKI

\section{Cases of soldiers' desertion to Poland from neighbouring countries in the years 1920-1939}

IN 1920-1939, at least several hundred soldiers fled to Poland from neighbouring countries. Moreover, Hungarian and even French soldiers sought refuge amongst the Polish people. These deserters were persecuted due to their nationality, religion and political views. This was particularly true for soldiers of the Red Army and Wehrmacht. Moreover, there were also soldiers who had committed crimes in their countries, mainly from Czechoslovakia and Romania.

Deserters from foreign countries could be accepted as political refugees, who were provided with a place of residence and employment, after thorough interrogation and arduous verification. The procedure concerning deserters from foreign countries was specified in the resolutions of March and April 1923.

Such actions were needed for the sake of national security. Otherwise, an apparent refugee quickly turned out to be either a spy or a saboteur. Despite limited trust to deserters, information obtained from them was sometimes 
valuable for the intelligence services. This was the case in spring 1936 when an interrogation of a Lithuanian deserter considerably broadened knowledge of the Polish intelligence about the Lithuanian army.

Deserters were also valuable for Polish propaganda which, particularly in the summer 1939, publicized cases of German soldiers fleeing to Poland. Such actions were aimed at lowering the morale of the German army and raising the spirits among Polish soldiers and citizens.

Keywords: Deserters, escape, Poland, soldiers, army, neighbouring countries. 